\title{
Analysis of fetch-limited wave growth using high-frequency radars in the Gulf of Tehuantepec
}

\section{Análisis del crecimiento del oleaje limitado por el fetch usando radares de alta frecuencia en el golfo de Tehuantepec}

\author{
Vladimir G Toro ${ }^{1}$, Francisco J Ocampo-Torres ${ }^{1}$, Pedro Osuna ${ }^{1}$, Héctor García-Nava², \\ Xavier Flores-Vidal'2, Reginaldo Durazo ${ }^{3}$ \\ ${ }^{1}$ Departamento de Oceanografía Física, CICESE, Carretera Ensenada-Tijuana No. 3918, Zona Playitas, \\ CP 22860, Ensenada, Baja California, México. \\ 2 Instituto de Investigaciones Oceanológicas, Universidad Autónoma de Baja California (UABC), Km. 103 \\ Carretera Tijuana-Ensenada, CP 22860, Ensenada, Baja California, México. \\ ${ }^{3}$ Facultad de Ciencias Marinas, Universidad Autónoma de Baja California, Km. 103 Carretera Tijuana- \\ Ensenada, CP 22860, Ensenada, Baja California, México.
}

*Corresponding author. Email: vtoro@cicese.edu.mx, vgtoro@gmail.com

\begin{abstract}
Fetch-limited wave growth was analyzed using high spatial and temporal resolution measurements obtained with high-frequency (HF) radars. To calculate the wave spectrum, the second-order echo $\left(S_{2 N}\right)$ was extracted from the Doppler spectrum and mapped to the wave frequency domain. The conversion of $S_{2 N}$ to the wave frequency spectrum was carried out using a linear parametric model dependent on wind speed. Wave growth, represented by the dimensionless energy and peak frequency as a function of dimensionless fetch, was determined from the spectra calculated for 25 cells $\left(\sim 400 \mathrm{~km}^{2}\right)$ in the vicinity of a moored Air-Sea Interaction Spar buoy. The buoy data were used as reference and to provide the wind information required for the wave growth analysis. The simultaneous data from the buoy and HF radars showed a suitable agreement with the wave growth curves. The analysis of the 25 cells showed an adequate agreement and certain dispersion around the growth curves. Possible causes of this dispersion are related to errors in the estimation of the frequency spectrum and fetch, and the assumption of homogeneous wind conditions. From the limited data set used, it was not possible to prove any impact of swell on wave growth; however, it is possible that analysis over a wider range of swell heights may provide this evidence. Nevertheless, the results suggest that the linear parametric model is able to reproduce fetch-limited wave growth. This work represents the first effort focused on fetch-limited wave growth using HF radars.
\end{abstract}

Key words: fetch-limited wave growth, high-frequency radars, ASIS buoy, Gulf of Tehuantepec, swell.

RESUMEN. Se analizó el crecimiento del oleaje limitado por el fetch utilizando mediciones de alta resolución espaciotemporal obtenidas con radares de alta frecuencia (HF). Para calcular el espectro del oleaje, el eco de segundo orden $\left(S_{2 N}\right)$ fue extraído del espectro Doppler y mapeado al dominio de las frecuencias del oleaje. La conversión de $S_{2 N}$ al espectro del oleaje se realizó mediante un modelo paramétrico lineal que depende de la velocidad del viento. El crecimiento del oleaje local, representado por la energía y la frecuencia asociada al pico espectral adimensional en función del fetch adimensional, se determinó a partir de los espectros del oleaje calculados para 25 nodos ( $\sim 400 \mathrm{~km}^{2}$ ) alrededor del sitio de anclaje de una boya Air-Sea Interaction Spar. Los datos de la boya se utilizaron como referencia y para proveer la información del viento necesaria para el análisis del crecimiento del oleaje. Los datos simultáneos de la boya y los radares HF presentaron una concordancia adecuada con las curvas de crecimiento del oleaje. El análisis en el dominio de los 25 nodos mostró una correlación significativa y cierta dispersión alrededor de las curvas de crecimiento. Las causas probables de esta dispersión están asociadas con errores en el cálculo del espectro del oleaje y del fetch, y a la suposición de condiciones de viento homogéneo. No fue posible determinar la influencia del swell en el crecimiento del oleaje con el set limitado de datos utilizado; sin embargo, es posible que un análisis con mayor variación de la altura del swell podría proveer esta evidencia. No obstante, los resultados sugieren que, con el modelo paramétrico lineal, es posible reproducir el crecimiento del oleaje limitado por el fetch. Este trabajo representa el primer esfuerzo enfocado al análisis del crecimiento del oleaje utilizando mediciones de radares HF.

Palabras clave: crecimiento del oleaje, radares de alta frecuencia, boya ASIS, golfo de Tehuantepec, swell.

\section{INTRODUCTION}

Understanding the processes governing the generation, growth, and evolution of ocean waves is necessary to predict their effects on coastal and ocean dynamics. In particular,

\section{INTRODUCCIÓN}

Entender los procesos de generación, crecimiento y evolución del oleaje es necesario para predecir sus efectos en la dinámica oceánica y costera. De estos tres aspectos, el 
wave growth data can provide valuable insight into the complex physics of wave evolution (Young and Verhagen 1996). Waves are generated and grow as a result of the force exerted by the wind on the sea surface. Strong, storm-associated winds in the open ocean generate waves that can travel thousands of kilometers. Storms occur randomly in space and time; hence, measuring wave growth is difficult because there is no prior knowledge of where and when they will originate and sufficient wave-measuring instruments are not in place. Waves that are generated and begin to grow in an area affected by strong winds are typically referred to as wind sea. On the other hand, wave growth can also be influenced by physical mechanisms such as atmospheric stability, swell, wind variability (Hwang et al. 2011), wave-current interactions (Kahma and Calkoen 1992), and the distance over which wave growth occurs, called the fetch (Ardhuin et al. 2007).

For the analysis of wave growth under controlled conditions, the wind is considered homogeneous and the fetch is defined by the orthogonal wind direction relative to the coastline. In situ measurements rarely comply with these requirements since wind fields are usually not homogeneous (Hwang et al. 2011) and the orientation of the coast relative to wind direction is perpendicular only during certain wind conditions (Ardhuin et al. 2007, Bottema and van Vledder 2008). Wave growth has been analyzed using in situ measurements (Hasselmann et al. 1973, Kahma 1981, Young and Verhagen 1996, Bottema and van Vledder 2009), a combination of in situ measurements and numerical simulations (Ardhuin et al. 2007), data generated by numerical models (Tuomi et al. 2012), and altimeter measurements (Ebuchi 1999).

In the Gulf of Tehuantepec (Mexico; fig. 1a), fetchlimited wave growth has been investigated under strong wind conditions. In this region, these strong winds, known as Tehuanos, occur mainly in winter. They blow offshore during one to several days, with wind speeds exceeding $20 \mathrm{~m} \mathrm{~s}^{-1}$ (García-Nava et al. 2009). On reaching the Pacific Ocean, Tehuano winds generate eddies and modify the circulation patterns of the Gulf of Tehuantepec (Flores-Vidal et al. 2011, Velázquez-Muñoz et al. 2014). These eddies intensify due to the presence of coastal currents (Velázquez-Muñoz et al. 2011, Pantoja et al. 2012). Moreover, in the gulf, Tehuano winds create a wave generation and growth area near the coast that extends southwestward. Romero and Melville (2010) undertook aircraft wave measurements of a 500-km-long fetch using two laser instruments with high spatial resolution for $2 \mathrm{~h}$. Ocampo-Torres et al. (2011) performed simultaneous wind and wave measurements using an Air-Sea Interaction Spar (ASIS) buoy as part of the experiment Air-Sea Interaction (INTOA). During this experiment, Doppler spectra coincident in time and space with the ASIS buoy measurements were also obtained with a highfrequency (HF) radar system.

For several decades, HF radar has been considered a promissory technology for the calculation of ocean current crecimiento del oleaje puede proveer información valiosa en la física compleja de la evolución del oleaje (Young y Verhagen 1996). El oleaje se genera y crece por la acción que el viento ejerce sobre la superficie del mar. Los vientos fuertes asociados a tormentas en el océano abierto generan olas que se pueden desplazar miles de kilómetros. La existencia espaciotemporal de estas tormentas es normalmente aleatoria; por lo tanto, es difícil ubicar suficientes instrumentos en las zonas de generación que permitan medir el crecimiento del oleaje porque no se sabe dónde o cuándo puedan ocurrir las tormentas. El oleaje generado dentro de la zona de fuertes vientos y que comienza a crecer es comúnmente llamado oleaje local. Por otro lado, el crecimiento del oleaje puede estar influenciado por mecanismos físicos tales como la estabilidad atmosférica, el oleaje generado por tormentas lejanas (swell), la variabilidad del viento (Hwang et al. 2011), las interacciones ola-corriente (Kahma y Calkoen 1992) y la distancia sobre la cual se lleva a cabo el crecimiento del oleaje, también llamada fetch (Ardhuin et al. 2007).

Para el análisis del crecimiento del oleaje bajo condiciones controladas, se requiere que el viento sea homogéneo y el fetch sea definido mediante la dirección del viento ortogonal a la línea de costa. Las mediciones in situ raramente cumplen con estos requisitos ya que los campos de viento normalmente no son homogéneos (Hwang et al. 2011) y la orientación de la costa respecto a la dirección del viento solamente es perpendicular bajo ciertas condiciones de viento (Ardhuin et al. 2007, Bottema y van Vledder 2008). El crecimiento del oleaje se ha analizado a partir de mediciones in situ (Hasselmann et al. 1973, Kahma 1981, Young y Verhagen 1996, Bottema y van Vledder 2009), combinando mediciones in situ y simulaciones numéricas (Ardhuin et al. 2007), usando información de modelos numéricos (Tuomi et al. 2012) y utilizando mediciones con altímetros (Ebuchi 1999).

En el golfo de Tehuantepec (México, fig. 1a), se han llevado a cabo campañas de medición para estudiar el crecimiento del oleaje limitado por el fetch bajo condiciones de vientos fuertes. Estos vientos, llamados tehuanos, se presentan en esta región principalmente en invierno, y soplan de tierra a mar durante uno a varios días con velocidades de viento mayores que $20 \mathrm{~m} \mathrm{~s}^{-1}$ (García-Nava et al. 2009). Los tehuanos, al llegar al océano Pacífico, modifican los patrones de circulación del golfo de Tehuantepec generando remolinos (Flores-Vidal et al. 2011, Velázquez-Muñoz et al. 2014), que se intensifican debido a la presencia de corrientes costeras (Velázquez-Muñoz et al. 2011, Pantoja et al. 2012). Además, en el golfo, los tehuanos crean una zona de generación y crecimiento del oleaje cerca de la costa que se extiende hacia el suroeste. Romero y Melville (2010) realizaron mediciones del oleaje desde un avión en el golfo utilizando dos instrumentos con tecnología laser; con estas mediciones, 


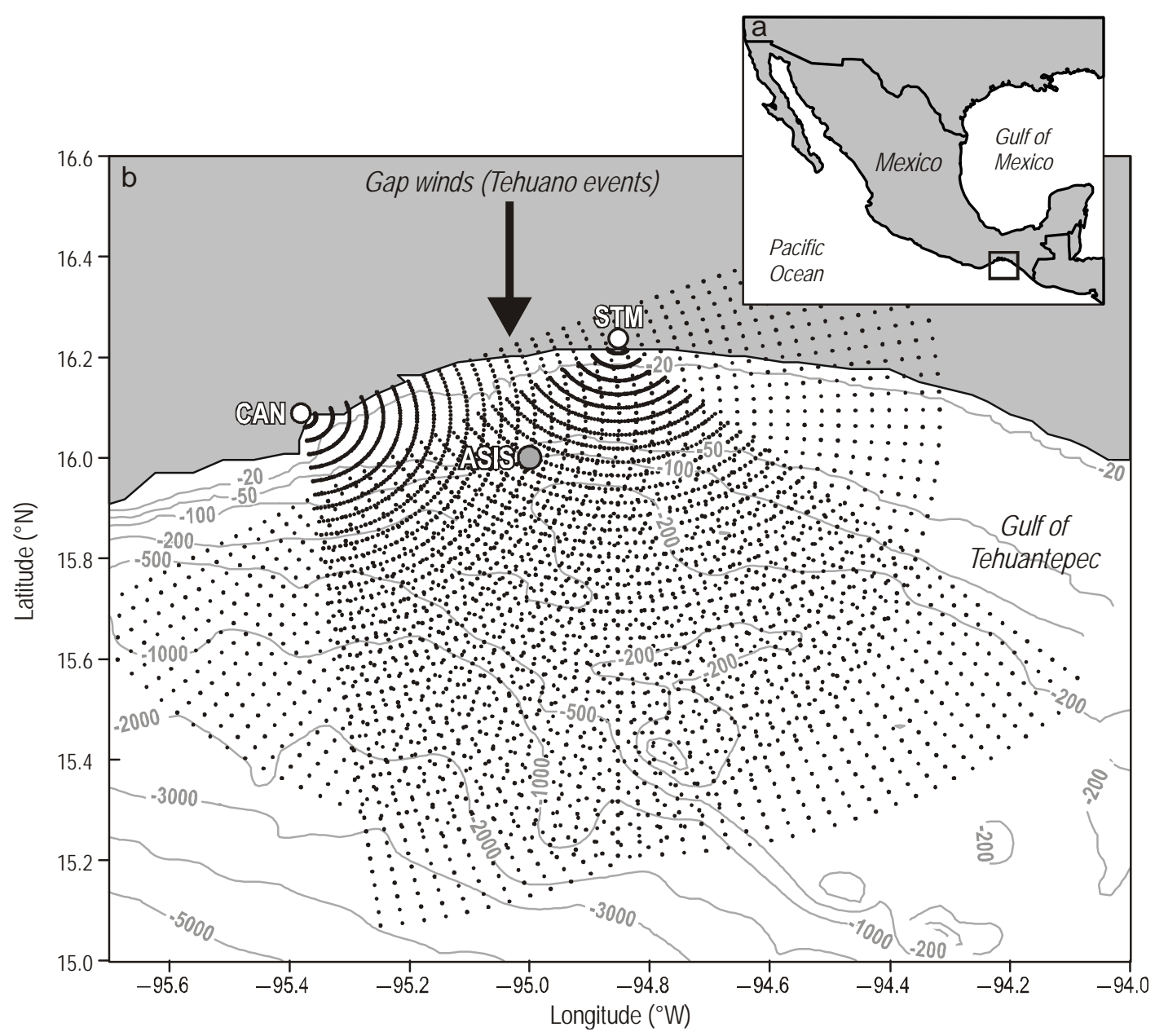

Figure 1. Study area. (a) Location of the Gulf of Tehuantepec. (b) Coverage area of the phased-array high-frequency radar system installed during the INTOA experiment field campaign. The two radar stations (CAN and STM, white circles), ASIS buoy location (gray circle), and prevailing direction of Tehuano winds (black arrow) are shown.

Figura 1. Área de estudio. (a) Ubicación del golfo de Tehuantepec. (b) Área de cobertura del sistema de radar de alta frecuencia instalado durante la campaña de medición del experimento INTOA. Se muestran las dos estaciones de radar (CAN y STM, círculos blancos), la posición de la boya ASIS (círculo gris) y la dirección predominante de los vientos Tehuanos (flecha negra).

and wave spectra (Crombie 1955). Radar systems have been used as complementary instruments in studies measuring ocean variables (Wyatt et al. 2003), in studies undertaking numerical simulations with current data assimilation (Breivik and Saetra 2001), and in renewable energy studies estimating potential wave energy (Wyatt 2012). A HF radar system emits and receives radio frequencies. Installed at the coast, the system will radiate electromagnetic waves that travel close to the sea surface. The electromagnetic waves are backscattered by the sea surface with a wavelength equal to half the wavelength of the emitted radiation (Bragg condition), and the signal is recorded in units of power or voltage (Barrick et al. 1974). The frequency of the reflected signal is modified by the speed of surface waves and ocean currents, and the change relative to the emitted frequency is called the Doppler frequency. The received signal power can be represented as a function of the Doppler frequency and distance estos autores obtuvieron información del oleaje con alta resolución espacial a lo largo de un fetch de hasta $500 \mathrm{~km}$ en intervalos de hasta $2 \mathrm{~h}$. Ocampo-Torres et al. (2011) realizaron mediciones simultáneas de viento y oleaje utilizando una boya Air-Sea Interaction Spar (ASIS) durante el experimento Interacción Océano-Atmósfera (INTOA). Durante este experimento, también se obtuvieron espectros Doppler con un sistema de radares de alta frecuencia (HF, por sus siglas en inglés) coincidentes en espacio y tiempo con las mediciones de la boya ASIS.

El radar HF ha sido considerado desde hace varias décadas como una tecnología promisoria para el cálculo del espectro del oleaje y las corrientes oceánicas (Crombie 1955). Estos radares se han utilizado como sistemas complementarios en campañas de medición de variables oceánicas (Wyatt et al. 2003), trabajos de simulaciones numéricas con 
from the radar or as a function of the Doppler frequency (called Doppler spectrum, fig. 2). A Doppler spectrum consists of two prominant signals, known as first-order peaks, surrounded by a continuous weaker echo, known as secondorder echo. First-order peaks appear in the Doppler spectrum due to the presence of waves that obey the Bragg condition and that move towards or away from the transmitter. The difference $(\Delta \omega)$ between the frequency associated with firstorder peaks and the theoretical Bragg frequency is used to calculate the velocity components of surface currents (fig. 2).

Second-order echoes are generated by a combination of hydrodynamic and electromagnetic processes. The information provided by these echoes is used to estimate the ocean wave spectrum, using either an integral equation (Barrick 1972, Wyatt 1990, Hisaki 1996, Hashimoto and Tokuda 1999) or a linear relationship between the ocean wave spectrum and the second-order echo (Hasselmann 1971, Gurgel et al. 2006, Toro 2014). Some authors have suggested that the peaks associated with ocean swell and wind sea can be visually observed in the second-order echoes (Lipa et al. 1981, fig. 2). The linear approximation to the integral equation

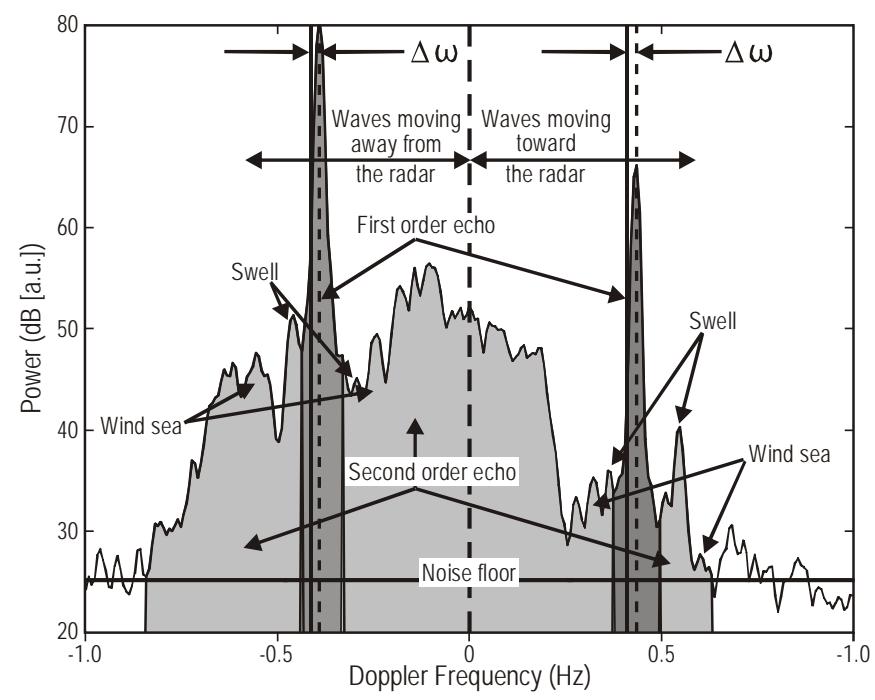

Figure 2. Main characteristics of a typical Doppler spectrum. Positive and negative Doppler frequencies are associated with waves moving toward and away from the radar, respectively. Information of the first peak is shown by dark gray areas. The Bragg frequency and first-order peak frequency values are shown in solid and dashed, black vertical lines, respectively. Information of the second-order echoes is shown in the light gray areas. $\Delta \omega$ is the difference between the frequency associated with first-order peaks and the theoretical Bragg frequency.

Figura 2. Principales características de un típico espectro Doppler. La frecuencia Doppler positiva y negativa se asocia con las olas que se acercan y alejan del radar, respectivamente. La información de los picos de primer orden se muestra en las zonas de color gris oscuro. Los valores de las frecuencias Bragg y del pico de primer orden se muestran con una línea vertical negra sólida y una discontinua, respectivamente. La información de los ecos de segundo orden se muestran en las zonas de color gris claro. $\Delta \omega$ es la diferencia entre la frecuencia asociada con los picos de primer orden y la frecuencia Bragg teórica. asimilación de datos de corrientes (Breivik y Saetra 2001) y en trabajos de energía renovable para estimar la energía potencial del oleaje (Wyatt 2012). El radar HF es un sistema de emisión y recepción de radiofrecuencias que se instala en la costa. Un radar HF irradia ondas electromagnéticas que viajan cerca de la superficie del mar. Las ondas electromagnéticas son reflejadas hacia el radar por olas que tienen una longitud de onda igual a la mitad de la longitud de onda emitida por el radar (condición Bragg), y la señal es registrada en unidades de potencia o voltaje (Barrick et al. 1974). La frecuencia de la señal reflejada se modifica debido a la rapidez de las olas superficiales y a las corrientes oceánicas, y el cambio respecto a la frecuencia emitida es llamado frecuencia Doppler. La potencia de la señal recibida se puede representar en función de la frecuencia Doppler y de la distancia desde el radar, o bien en función de la frecuencia Doppler (llamado espectro Doppler, fig. 2). Un espectro Doppler está compuesto por dos señales prominentes, conocidas como picos de primer orden, rodeados por un eco continuo de menor potencia, conocido como eco de segundo orden. Los picos de primer orden aparecen en el espectro Doppler debido a la presencia de olas que cumplen la condición Bragg y que se acercan o se alejan del radar. La diferencia $(\Delta \omega)$ entre la frecuencia asociada a estos picos de primer orden y la frecuencia Bragg teórica se utiliza para calcular las componentes de la velocidad de las corrientes superficiales (fig. 2).

Los ecos de segundo orden se generan por una combinación de procesos hidrodinámicos y electromagnéticos. La información de estos ecos es utilizada para estimar el espectro del oleaje, ya sea a través de una ecuación integral (Barrick 1972, Wyatt 1990, Hisaki 1996, Hashimoto y Tokuda 1999) o por medio de una relación lineal entre el espectro del oleaje y el eco de segundo orden (Hasselmann 1971, Gurgel et al. 2006, Toro 2014). Algunos autores han sugerido que los picos asociados al swell y al oleaje local pueden ser localizados visualmente en los ecos de segundo orden (Lipa et al. 1981, fig. 2). La aproximación lineal a la ecuación integral propuesta por Hasselmann (1971) supone que las áreas de los ecos de segundo orden son proporcionales al espectro en frecuencia del oleaje a través de la razón $T_{1} / T_{2}$ y que el mapeo de las frecuencias Doppler al dominio de las frecuencias del oleaje es lineal. $T_{1}$ es una función de la potencia reflejada por el oleaje y la potencia emitida por el radar. $T_{2}$ es una función de transferencia definida por un coeficiente de acoplamiento entre dos olas que incluye interacciones hidrodinámicas y electromagnéticas. Gurgel et al. (2006) y Toro (2014) aproximan la razón $T_{1} / T_{2}$ usando un parámetro empírico $\left(\alpha_{F}=T_{1} / T_{2}\right)$. Gurgel et al. (2006) calcularon $\alpha_{F}$ como los coeficientes de regresión obtenidos al comparar los ecos de segundo orden normalizados y los espectros del oleaje medidos con una boya durante dos 
proposed by Hasselmann (1971) assumes that the areas associated with the second-order echoes are proportional to the wave frequency spectrum through the $T_{1} / T_{2}$ ratio and that the mapping of the Doppler frequencies to the wave frequency domain is linear. $T_{1}$ is a function of the power reflected by ocean waves and the power emitted by the radar system. $T_{2}$ is a transfer function defined by a two-wave coupling coefficient that includes hydrodynamic and electromagnetic interactions. For the $T_{1} / T_{2}$ ratio approximation, Gurgel et al. (2006) and Toro (2014) used an empirical parameter $\left(\alpha_{F}=T_{1} / T_{2}\right)$. Gurgel et al. (2006) calculated $\alpha_{F}$ as the regression coefficients obtained on comparing normalized secondorder echoes and buoy measurements of ocean wave spectra taken over two months. Toro (2014) used HF radar and buoy data obtained over 15 days, and calculated the mean value of $\alpha_{F}$ as a function of the ratio of swell energy $\left(E_{\text {SWELL }}\right)$ to wind sea energy $\left(E_{S E A}\right)$ or as a function of wind speed $\left(U_{10}\right)$. Using the linear model proposed by Hasselmann (1971), second-order echo information, and the parameter $\alpha_{F}$, Gurgel et al. (2006) and Toro (2014) obtained wave frequency spectra from HF radar measurements. Comparisons of wave frequency spectra, significant wave height $\left(H_{S}\right)$, and peak frequency of wind sea $\left(F_{S E A}\right)$ obtained in the Gulf of Tehuantepec from in situ measurements and HF radars showed that the parameter $\alpha_{F}$ proposed by Toro (2014) is suitable to obtain ocean wave information. The measurements used by Toro (2014) were obtained during the INTOA experiment; some of the in situ data were used to calibrate the values of $\alpha_{F}$ and some were used to validate the ocean wave data estimated with the proposed method. The objective of our study is to determine fetch-limited wave growth based on the wave frequency spectrum calculated with a linear parametric model that uses HF radar data.

\section{MATERIALS AND METHODS}

The data used in this paper correspond to measurements performed during the INTOA experiment (Ocampo-Torres et al. 2011). This experiment was conducted from February to April 2005 in the Gulf of Tehuantepec, on the Pacific coast of southern Mexico (fig. 1a). This region is distinctive because it receives swell almost all year long that is generated in the Antarctic Ocean and by Tehuano wind events. Several Tehuano wind events occurred during the study period. For the direct measurement of ocean waves and wind speed and direction, an ASIS buoy was deployed at $60 \mathrm{~m}$ depth at $16^{\circ} \mathrm{N}, 95^{\circ} \mathrm{W}$. The wind components were measured by a sonic anemometer situated $6.5 \mathrm{~m}$ above sea level and transformed to a height of $10 \mathrm{~m}\left(U_{10}\right)$. Ocean wave data were measured by a capacitance wire array (García-Nava et al. 2009) and used to calculate the wave spectrum; the directional wave spectrum was calculated only for the first 10 days, but the wave frequency spectrum data are available for the entire study period.

During the INTOA experiment, a high-frequency radar system consisting of two radar stations, each one with an meses de mediciones. Toro (2014) utilizó datos medidos por un radar HF y una boya durante 15 días para calcular el valor medio de $\alpha_{F}$ en función de la razón entre la energía asociada al swell $\left(E_{S W E L L}\right)$ y la energía asociada al oleaje local $\left(E_{S E A}\right)$ o en función de los valores de la velocidad del viento $\left(U_{10}\right)$. Con base en el modelo lineal propuesto por Hasselmann (1971), la información del eco de segundo orden y el parámetro $\alpha_{F}$, Gurgel et al. (2006) y Toro (2014) obtuvieron espectros en frecuencia del oleaje a partir de mediciones con radares HF. Las comparaciones de los espectros en frecuencia, la altura significante $\left(H_{S}\right)$ y la frecuencia asociada al pico espectral del oleaje local $\left(F_{S E A}\right)$ obtenidos a partir de mediciones in situ y de información obtenida con radares HF en el golfo de Tehuantepec mostraron que el parámetro $\alpha_{F}$ propuesto por Toro (2014) es adecuado para obtener información del oleaje. Las mediciones utilizadas por Toro (2014) se obtuvieron durante el experimento INTOA; parte de los valores medidos in situ fueron usados para calibrar los valores del parámetro $\alpha_{F}$ y otra parte para validar la información del oleaje calculada con el método propuesto. El objetivo de este trabajo es determinar el crecimiento del oleaje limitado por el fetch usando espectros en frecuencia del oleaje calculados con un modelo paramétrico lineal que utiliza información obtenida de radares HF.

\section{MATERIALES Y MÉTODOS}

Los datos utilizados en este trabajo corresponden a las mediciones realizadas durante el experimento INTOA (Ocampo-Torres et al. 2011). Este experimento se llevó a cabo de febrero a abril de 2005 en el golfo de Tehuantepec, ubicado al sur de México en el océano Pacífico (fig. 1a). Esta región se distingue porque recibe casi todo el año swell que se produce en el océano Antártico y por la ocurrencia de eventos tehuanos. Durante el periodo del experimento sucedieron varios eventos tehuanos. Las mediciones directas del oleaje y de la rapidez y dirección del viento se realizaron con una boya ASIS ubicada a los $16^{\circ} \mathrm{N}$ y $95^{\circ} \mathrm{W}$ sobre una profundidad de $60 \mathrm{~m}$. Las componentes del viento fueron medidas por un anemómetro sónico ubicado a $6.5 \mathrm{~m}$ por encima del nivel del mar y transformados a una altura de $10 \mathrm{~m}\left(U_{10}\right)$. La información del oleaje fue medida por un arreglo de alambres capacitores (García-Nava et al. 2009) y fue utilizada para calcular el espectro del oleaje. El espectro direccional solamente se midió durante los 10 primeros días, pero los registros del espectro en frecuencia están disponibles para el periodo completo de observaciones.

Durante el experimento INTOA, se instaló un sistema de radar HF compuesto por dos estaciones, cada una con un arreglo de 16 antenas receptoras. Las estaciones fueron playa Cangrejo (CAN; 16 $04^{\prime} 14^{\prime \prime}$ N, 95 $21^{\circ} 45^{\prime \prime}$ W) y Santa María del Mar (STM; 16 $16^{\circ} 56^{\prime \prime}$ N, 94 $01^{\prime} 59^{\prime \prime}$ W). Cada 
array of 16 receiving antennas, was installed. The two sta-

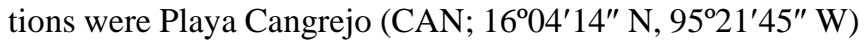
and Santa María del Mar (STM; 16 $16^{\circ} 56^{\prime \prime}$ N, 94 $01^{\prime} 59^{\prime \prime}$ W). Each station measured the continuous electromagnetic signal backscattered by the ocean waves at 10-min intervals and operated at a frequency of $16.3 \mathrm{MHz}$, providing a coverage of between 80 and $120 \mathrm{~km}$.

\section{Wave frequency spectra from HF radar measurements}

The wave directional spectrum $(S)$ can be calculated using information from the second-order echo of the Doppler spectrum $\left(\sigma_{2}\right)$ by inverting the integral equation proposed by Hasselmann (1971) and Barrick (1972): estación midió la señal electromagnética continua reflejada de manera difusa por el oleaje en intervalos de $10 \mathrm{~min}$. La frecuencia de operación de los radares fue de $16.3 \mathrm{MHz}$, y esto permitió realizar mediciones con un alcance de entre 80 y $120 \mathrm{~km}$.

\section{Espectros en frecuencia del oleaje a partir de mediciones con radares $\mathrm{HF}$}

El espectro direccional del oleaje $(S)$ puede ser calculado con la información del eco de segundo orden del espectro Doppler $\left(\sigma_{2}\right)$ realizando la inversión de la ecuación integral propuesta por Hasselmann (1971) y Barrick (1972):

$$
\sigma_{2}=\left(\omega_{d}\right) 2^{6} \pi k_{t}^{4} \sum_{m_{1}, m_{2}= \pm 1} \int_{-\infty}^{\infty} \int_{-\infty}^{\infty}|\Gamma|^{2} S\left(c_{1} \boldsymbol{k}_{\mathbf{1}}\right) S\left(c_{2} \boldsymbol{k}_{2}\right) \delta\left(\omega_{d}-c_{1}\left(g k_{1}\right)^{0.5}-c_{2}\left(g k_{2}\right)^{0.5}\right) d p d q
$$

where $\omega_{d}$ is the Doppler frequency, $\Gamma$ is a coupling coefficient that includes nonlinear hydrodynamic $\left(\Gamma_{H}\right)$ and electromagnetic $\left(\Gamma_{E M}\right)$ effects, $c_{1}$ and $c_{2}$ represent a change in sign ( \pm ), $\delta$ is the Dirac delta function, and $\boldsymbol{k}_{1}$ and $\boldsymbol{k}_{2}$ are wavenumber vectors (of magnitudes $k_{1}$ and $k_{2}$, respectively). The spatial wavenumber $p$ is defined along the axis of radar measurement and $q$ is perpendicular to $p$. According to Hasselmann (1971), a linear expression can be obtained from equation (1) that relates the wave frequency spectrum $\left(S_{F}\right)$ to the ratio between the power of the second-order echo and the integrated power of the first-order echo through $T_{1} / T_{2}$ :

$$
S_{F}\left(\omega_{d} \pm \omega_{b}\right)=\frac{T_{1}}{T_{2}} \frac{\sigma_{2}\left(\omega_{d}\right)}{\sigma_{1}\left(\omega_{d}\right)}=\frac{T_{1}}{T_{2}} S_{2 N}\left(\omega_{d}\right)
$$

where $\omega_{b}$ is the Bragg frequency, $\sigma_{1}$ is the information associated with the first-order echo and $S_{2 N}$ is the normalized second-order echo defined as the $\sigma_{2} / \sigma_{1}$ ratio. Gurgel et al. (2006) assume that $S_{F}$ is proportional to the sum of the signals in the frequency bands of the second-order echo through parameter $\alpha_{F}$ :

$$
S_{F}\left(\omega_{F}\right)=\alpha_{F}\left(S_{2 N i}+S_{2 N j}\right)=\alpha_{F}\left(S_{2 N}\right)
$$

where $\omega_{F}$ is the wave frequency and the indices $i$ and $j$ indicate the positive and negative parts of the second-order echo. Combining equations (2) and (3), it can be deduced that $\alpha_{F}$ is proportional to the $T_{1} / T_{2}$ ratio. The $\alpha_{F}$ values are obtained by calculating the $S_{F} / S_{2 N}$ ratio and are thus a function of the wave frequency. In the present study, $\alpha_{F}$ was used as a function of $U_{10}$ as proposed by Toro (2014), in which the $U_{10}$ domain was described by four scales: $4<U_{10} \leq 8$, donde $\omega_{d}$ es la frecuencia Doppler, $\Gamma$ es un coeficiente de acoplamiento que incluye los efectos no lineales hidrodinámicos $\left(\Gamma_{H}\right)$ y electromagnéticos $\left(\Gamma_{E M}\right), c_{1}$ y $c_{2}$ representan un cambio de signo $( \pm)$, $\delta$ es la función delta de Dirac, y $\boldsymbol{k}_{1} \mathrm{y}$ $\boldsymbol{k}_{2}$ son vectores número de onda (con magnitudes $k_{1} \mathrm{y} k_{2}$, respectivamente) asociados al oleaje. El número de onda espacial $p$ está definido a lo largo del eje de medición del radar, y $q$ es perpendicular a $p$. De acuerdo con el trabajo de Hasselmann (1971), de la ecuación (1) se puede obtener una expresión lineal en la cual se relaciona el espectro en frecuencia del oleaje $\left(S_{F}\right)$ con la razón entre la potencia del eco de segundo orden y la potencia integrada del eco de primer orden a través de $T_{1} / T_{2}$ :

$$
S_{F}\left(\omega_{d} \pm \omega_{b}\right)=\frac{T_{1}}{T_{2}} \frac{\sigma_{2}\left(\omega_{d}\right)}{\sigma_{1}\left(\omega_{d}\right)}=\frac{T_{1}}{T_{2}} S_{2 N}\left(\omega_{d}\right)
$$

donde $\omega_{b}$ es la frecuencia de Bragg, $\sigma_{1}$ es la información asociada al eco de primer orden y $S_{2 N}$ es el eco de segundo orden normalizado definido como la razón $\sigma_{2} / \sigma_{1}$. Gurgel et al. (2006) suponen que $S_{F}$ es proporcional a la suma de las señales en las bandas de frecuencia del eco de segundo orden por medio del parámetro $\alpha_{F}$ :

$$
S_{F}\left(\omega_{F}\right)=\alpha_{F}\left(S_{2 N i}+S_{2 N j}\right)=\alpha_{F}\left(S_{2 N}\right)
$$

donde $\omega_{F}$ es la frecuencia del oleaje, los índices $i$ y $j$ se refieren a la parte positiva y negativa del eco de segundo orden. Combinando las ecuaciones (2) y (3), es posible deducir que $\alpha_{F}$ es proporcional a la razón $T_{1} / T_{2}$. Los valores de $\alpha_{F}$ se obtienen calculando la razón $S_{F} / S_{2 N}$ y, por lo tanto, son función de la frecuencia del oleaje. En este trabajo, se utilizó 
$8<U_{10} \leq 12,12<U_{10} \leq 16$, and $U_{10}>16 \mathrm{~m} \mathrm{~s}^{-1}$. The following steps were performed to correctly obtain $S_{2 N}$ values.

The Doppler spectra from each radar station were mapped onto a rectangular grid of $40 \times 50$ cells with a resolution of $4 \times 4 \mathrm{~km}$ (fig. 1b). The measurement period used here was 22 February to 10 March 2005 . We selected 25 cells close to the position of the moored ASIS buoy $\left(\sim 400 \mathrm{~km}^{2}\right)$ in order to increase the total number of data to be processed. The Doppler spectra used for the wave calculations were selected depending on the noise level of each spectrum. The noise level can be inversely associated with the signal-to-noise ratio (SNR). The noise level was calculated using the technique of rank ordering of spectral energy proposed by Heron and Heron (2001). Selection was made considering the noise level of each spectrum and the average noise level. The average noise level, corresponding to a diurnal cycle, was defined using information from the Doppler spectra for the ASIS buoy location during the entire period of the INTOA experiment. To select the spectra with sufficient SNR, we assumed that the noise level was similar for all 25 cells. The diurnal cycle values of the noise level at the buoy location can thus be used as a threshold, below which the noise levels and their associated Doppler spectra are considered to have sufficient SNR. Only the spectra that complied with these requirements were used to extract the second-order echo. As the Santa María del Mar spectra showed low SNR values, the information from this radar station was not considered for the subsequent analyses. The Doppler frequencies of the selected spectra were corrected for the effect of ocean currents. This correction was performed using information on the frequency associated with the first-order peaks and the Bragg frequency $\left(\omega_{b}=\left[2 g k_{t}\right]^{0.5}\right.$, where $g$ is the acceleration due to gravity and $k_{t}$ is the emitted electromagnetic wavelength).

For the extraction of the second-order echo, we first calculated the ratio between the Doppler power spectrum and the weighting function proposed by Barrick (1977). This weighting function allowed us to modify the power of the Doppler spectrum only at frequency bands particularly sensitive to ocean wave direction. Four second-order echo frequency bands were then defined. We initially selected four frequencies associated with local minima in the vicinity of the first-order peaks. The local minima were found assuming that the first-order peaks can be approximated by two straight lines. A local minimum was defined when the difference between the frequency of the Doppler spectrum and the frequency associated with the straight lines was greater than the frequency resolution of the Doppler spectrum $(0.0075 \mathrm{~Hz})$. The four remaining frequencies associated with each local minimum, with which the frequency bands of the secondorder echoes can be defined, were calculated according to the noise level of the Doppler spectrum. These bands were defined by the previously mentioned local minimum values and by the frequencies where the power of the spectrum is lower or equal to the noise level. The frequencies of each of the four bands were mapped at wave frequencies by a linear el parámetro $\alpha_{F}$ en función de $U_{10}$ tal como lo propone Toro (2014), en el cual el dominio de $U_{10}$ se describió mediante cuatro escalas: $4<U_{10} \leq 8,8<U_{10} \leq 12,12<U_{10} \leq 16$ y $U_{10}>16 \mathrm{~m} \mathrm{~s}^{-1}$. A continuación se presentan una serie de pasos que permiten obtener los valores de $S_{2 N}$.

Los espectros Doppler de cada estación fueron mapeados a una malla rectangular de $40 \times 50$ nodos con una resolución de $4 \times 4 \mathrm{~km}$ (fig. 1b). El periodo de mediciones utilizado en este trabajo fue del 22 de febrero al 10 de marzo de 2005. Se seleccionaron los 25 nodos más cercanos a la posición de la boya ASIS $\left(\sim 400 \mathrm{~km}^{2}\right)$ y, de esta manera, se aumentó el número total de datos a procesar. Los espectros Doppler utilizados en los cálculos del oleaje fueron seleccionados de acuerdo con el nivel base de ruido de cada espectro. El nivel base de ruido se puede asociar de manera inversa al valor de la razón señal/ruido (SNR, por sus siglas en inglés). Para el cálculo del nivel base de ruido, se utilizó el método de ordenamiento por categorías de la energía espectral propuesto por Heron y Heron (2001). La selección se realizó teniendo en cuenta el nivel base de ruido de cada espectro y un nivel base de ruido promedio. El nivel base de ruido promedio, correspondiente a un ciclo diurno, se definió utilizando la información de los espectros Doppler en el nodo de la boya ASIS durante el periodo completo del experimento INTOA. Para la selección de los espectros con suficiente SNR, se supuso que el nivel base de ruido en los 25 nodos de interés era similar. Por lo tanto, es posible utilizar los valores del ciclo diurno del nivel base de ruido en el nodo de la boya ASIS como un umbral por debajo del cual los valores del nivel base de ruido y sus espectros Doppler asociados se consideran que tienen suficiente SNR. Sólo los espectros que cumplieron estos requisitos fueron utilizados para la extracción del eco de segundo orden. Los espectros de la estación Santa María del Mar mostraron valores bajos de SNR y, por lo tanto, la información de esta estación no se consideró en los análisis posteriores. Las frecuencias Doppler de los espectros seleccionados fueron corregidas debido al efecto de las corrientes oceánicas. Esta corrección se realizó utilizando información de la frecuencia asociada a los picos de primer orden y de la frecuencia Bragg $\left(\omega_{b}=\left[\begin{array}{lll}2 & g & k_{t}\end{array}\right]^{0.5}\right.$, donde $g$ es la aceleración debida a la gravedad y $k_{t}$ es la longitud de la onda electromagnética emitida).

Para la extracción del eco de segundo orden, primero se cálculo la razón entre la potencia del espectro Doppler y la función de peso propuesta por Barrick (1977). Esta función de peso permitió modificar la potencia del espectro Doppler en bandas de frecuencia particularmente sensibles a la dirección del oleaje. Posteriormente, se definieron cuatro bandas de frecuencia de ecos de segundo orden. Se seleccionaron en primer lugar cuatro frecuencias asociadas a mínimos locales ubicados alrededor de los picos de primer orden. Los mínimos locales se encontraron suponiendo que los picos de primer orden pueden aproximarse cada uno mediante dos líneas rectas. Se definió un mínimo local cuando la diferencia 
approximation that is a function of $U_{10}$ (Toro 2014) and the powers of the four bands were added $\left(S_{2 N}\right)$ according to equation (3). Finally, the wave frequency spectra were obtained using the $S_{2 N}$ product and the parametric function $\alpha_{F}$.

\section{Calculation of wind sea and swell energy values from the frequency spectrum}

Ocean wave spectra typically include information on swell and wind sea. To study wave growth it is necessary to separate $E_{S W E L L}$ and $E_{S E A}$ from total energy $\left(E_{T O T}\right)$. To identify $E_{S W E L L}$ and $E_{S E A}$ from the frequency spectrum $\left(S_{F}\right)$, we used a separation frequency $\left(f_{s}\right)$ calculated as described by Hwang et al. (2012):

$$
E_{T O T}=\int_{0}^{\infty} S_{F} d F=\int_{0}^{f_{S}} S_{F} d F+\int_{f_{s}}^{\infty} S_{F} d F=E_{S W E L L}+E_{S E A}
$$

The $E_{\text {SEA }}, E_{S W E L L}$, and $E_{T O T}$ values were used to calculate wind sea height $\left(H_{S E A}\right)$, swell height $\left(H_{S W E L L}\right)$, and $H_{S}$, assuming that wave heights follow a Rayleigh distribution and the free surface elevation follows a Gaussian distribution:

$$
\begin{gathered}
H_{S}=4 \sqrt{E_{T O T}} \\
H_{S E A}=4 \sqrt{E_{S E A}} \\
H_{S W E L L}=4 \sqrt{E_{S W E L L}}
\end{gathered}
$$

The wind-sea fraction (wsf) was calculated as the ratio of $E_{S E A}$ to $E_{T O T}$. Values of wsf between 0.5 and 1 are associated with high wind sea energy levels and those between 0 and 0.5 with high swell energy levels. In wave growth analyses, the peak frequency of wind sea $\left(F_{S E A}\right)$ is also used. Using information from the wind-sea-associated $S_{F}$ spectrum (integral between $f_{S}$ and $\infty$, eq. (4)), the $F_{S E A}$ value was defined as the frequency associated with the maximum value of spectral energy.

For the subsequent analyses we used only some of the HF radar and ASIS buoy measurements taken over the entire study period corresponding to the frequency spectra and associated $E_{S E A}, E_{S W E L L}, E_{T O T}$, and $F_{\text {SEA }}$ values. The selected data correspond to Tehuano events, when wind speed and direction were, respectively, $U_{10} \geq 8 \mathrm{~m} \mathrm{~s}^{-1}$ and $\theta=180^{\circ} \pm 10^{\circ}$ (nautical convention, $0^{\circ}=$ North, $90^{\circ}=$ East), approximately perpendicular to the coastline. To establish the correlation between the measured and calculated values, we used the estimate of three statistical errors: root mean square error (RMSE), bias, and correlation coefficient $\left(R^{2}\right)$. The $E_{S E A}$ and $F_{S E A}$ values were used to calculate the variables that describe wave growth. entre la frecuencia del espectro Doppler y la frecuencia asociada a las líneas rectas era mayor que la resolución en frecuencia del espectro Doppler $(0.0075 \mathrm{~Hz})$. Las cuatro frecuencias restantes asociadas con cada mínimo local, que permiten definir las bandas de frecuencia de los ecos de segundo orden, se calcularon de acuerdo con el valor del nivel base de ruido del espectro Doppler. Estas bandas fueron definidas por los valores mínimos locales antes mencionados y por las frecuencias donde la potencia del espectro Doppler es menor o igual que el nivel base de ruido. Las frecuencias de cada una de las cuatro bandas fueron mapeadas a frecuencias del oleaje mediante una aproximación lineal que es función de $U_{10}$ (Toro 2014), y luego se sumaron las potencias de las cuatro bandas $\left(S_{2 N}\right)$ de acuerdo con la ecuación (3). Finalmente, se obtuvieron los espectros en frecuencia del oleaje mediante el producto de $S_{2 N}$ y la función paramétrica $\alpha_{F}$.

\section{Cálculo de valores de energía del oleaje local y swell a partir del espectro en frecuencia}

Comúnmente, los espectros de oleaje incluyen información del swell y del oleaje local. Para estudiar el crecimiento del oleaje, se requiere separar $E_{S W E L L}$ y $E_{S E A}$ de la energía total $\left(E_{T O T}\right)$. Para identificar $E_{S W E L L}$ y $E_{S E A}$ a partir del espectro en frecuencia $\left(S_{F}\right)$, se calculó una frecuencia de separación $\left(f_{s}\right)$ según Hwang et al. (2012):

$$
E_{\text {TOT }}=\int_{0}^{\infty} S_{F} d F=\int_{0}^{f_{s}} S_{F} d F+\int_{f_{s}}^{\infty} S_{F} d F=E_{S W E L L}+E_{S E A}
$$

Con los valores de $E_{S E A}, E_{S W E L L}$ y $E_{T O T}$, se calculó $H_{S}$, la altura significante del oleaje local $\left(H_{S E A}\right)$ y la altura significante del swell $\left(H_{\text {SWELL }}\right)$, suponiendo que el oleaje tiene una distribución tipo Rayleigh y la superficie libre tiene una distribución gaussiana:

$$
\begin{gathered}
H_{S}=4 \sqrt{E_{T O T}} \\
H_{S E A}=4 \sqrt{E_{S E A}} \\
H_{S W E L L}=4 \sqrt{E_{S W E L L}}
\end{gathered}
$$

La fracción de la energía correspondiente al oleaje local (wind-sea fraction, wsf) se calculó como la razón entre $E_{S E A} \mathrm{y}$ $E_{\text {TOT. }}$ Los valores de wsf entre 0.5 y 1.0 se pueden asociar a niveles altos de energía del oleaje local y aquellos entre $0 \mathrm{y}$ 0.5 a niveles altos de energía del swell. En los análisis de crecimiento del oleaje también se utiliza el valor de la frecuencia asociada al pico espectral del oleaje local $\left(F_{S E A}\right)$. Con información del espectro $S_{F}$ asociado al oleaje local (integral entre 


\section{Expressions for wave growth}

Wave growth was analyzed by the evolution of the dimensionless energy $\left(\boldsymbol{E}_{\boldsymbol{S E A}}\right)$ and the dimensionless peak frequency $\left(\boldsymbol{F}_{S E A}\right)$ of wind sea, as a function of the dimensionless fetch $(\boldsymbol{X})$. Information on $E_{S E A}, F_{S E A}$, fetch $(X)$, and wind speed $\left(U_{10}\right)$ was used for the analysis. Wave growth can be defined according to the following expressions (Kitaigorodskii 1962):

$$
\begin{gathered}
\boldsymbol{E}_{S E A}=\frac{g^{2} E_{S E A}}{U_{10}^{4}} \\
\boldsymbol{F}_{S E A}=\frac{F_{S E A} U_{10}}{g} \\
\boldsymbol{X}=\frac{g X}{U_{10}^{2}}
\end{gathered}
$$

Using these expressions and multiple data bases of in situ measurements, Kahma and Calkoen (1992) and Hwang et al. (2011) derived empirical curves to describe wave energy growth under stable atmospheric conditions. In the present study, these empirical curves were used as reference to calculate the $\boldsymbol{E}_{\boldsymbol{S E A}}$ and $\boldsymbol{F}_{\boldsymbol{S E A}}$ values as a function of $\boldsymbol{X}$.

The $X$ value used in equations (8-10) was calculated by tracing a straight line between the point of study in the ocean and the coastline according to wind direction. To estimate $\boldsymbol{E}_{\boldsymbol{S E A}}, \boldsymbol{F}_{\boldsymbol{S E A}}$, and $\boldsymbol{X}$ values for the 25 cells in the vicinity of the moored ASIS buoy $\left(\sim 400 \mathrm{~km}^{2}\right)$, the wind field was assumed to be homogeneous and equal to the wind speed and direction measured by the buoy. Therefore, using the estimated $E_{S E A}$, $F_{S E A}$, and $X$ values, and assuming homogeneous wind conditions for the 25 cells, the values of $\boldsymbol{E}_{\boldsymbol{S E A}}, \boldsymbol{F}_{\boldsymbol{S E A}}$, and $\boldsymbol{X}$ were calculated according to equations (8-10).

The values of $\boldsymbol{E}_{\boldsymbol{S E A} \boldsymbol{A}}$ and $\boldsymbol{F}_{\boldsymbol{S E A} \boldsymbol{A}}$ as a function of $\boldsymbol{X}$ were initially analyzed using the buoy-derived values and the HF radar values for the buoy location. A linear regression line was fitted to the radar-derived $\boldsymbol{E}_{\boldsymbol{S E A}}$ and $\boldsymbol{F}_{\boldsymbol{S E A}}$ values as a function of $\boldsymbol{X}$. We also analyzed the values of $\boldsymbol{E}_{\boldsymbol{S E A}}$ and $\boldsymbol{F}_{\boldsymbol{S E A}}$ as a function of $\boldsymbol{X}$ corresponding to the 25 cells in the vicinity of the ASIS buoy. In this analysis we included the estimate of the mean values and standard deviations of $\boldsymbol{E}_{\boldsymbol{S E A}}$ and $\boldsymbol{F}_{\text {SEA }}$, binned relative to the $\boldsymbol{X}$ domain on a scale of $10^{2}$. Moreover, discrete $H_{S W E L L}$ and wsf values were used to study the effect of swell on wave growth. We used binned $H_{\text {SWELL }}$ values at intervals of $0.15 \mathrm{~m}$ between 0.5 and $1.1 \mathrm{~m}$, and binned wsf values at intervals of 0.1 between 0.35 and 0.85 .
$f_{S} \mathrm{y} \infty$, ec. (4)), se definió el valor de $F_{S E A}$ como la frecuencia asociada al valor máximo de energía espectral.

Para los análisis posteriores, del periodo completo de mediciones, se seleccionó una parte de la información obtenida a partir de mediciones de radar HF y medida por la boya ASIS correspondiente a los espectros en frecuencia y sus valores asociados de $E_{S E A}, E_{S W E L L}, E_{T O T}$ y $F_{S E A}$. La información seleccionada correspondió a periodos de eventos tehuanos, cuando la rapidez y la dirección del viento fueron, respectivamente, $U_{10} \geq 8 \mathrm{~m} \mathrm{~s}^{-1}$ y $\theta=180^{\circ} \pm 10^{\circ}$ (convención náutica, $0^{\circ}$ hacia el Norte, $90^{\circ}$ hacia el Este), aproximadamente perpendicular a la línea de costa. Para determinar la correlación entre los valores medidos y calculados, se utilizó la estimación de tres errores estadísticos: error cuadrático medio (RMSE), sesgo y coeficiente de correlación $\left(R^{2}\right)$. Con los valores de $E_{S E A}$ y $F_{S E A}$, se calcularon las variables que permiten describir el crecimiento del oleaje.

\section{Expresiones para el crecimiento del oleaje}

El crecimiento del oleaje se analizó mediante la evolución de la energía adimensional $\left(\boldsymbol{E}_{\boldsymbol{S E A}}\right)$ y la frecuencia adimensional asociada al pico espectral $\left(\boldsymbol{F}_{S E A}\right)$ del oleaje local, en función del fetch adimensional $(\boldsymbol{X})$. El análisis se realizó con información de $E_{S E A}, F_{S E A}$, del fetch $(X)$ y de la rapidez del viento $U_{10}$. El crecimiento del oleaje se puede expresar de acuerdo con las siguientes expresiones (Kitaigorodskii 1962):

$$
\begin{gathered}
\boldsymbol{E}_{S E \boldsymbol{A}}=\frac{g^{2} E_{S E A}}{U_{10}{ }^{4}} \\
\boldsymbol{F}_{S E \boldsymbol{A}}=\frac{F_{S E A} U_{10}}{g} \\
\boldsymbol{X}=\frac{g X}{U_{10}{ }^{2}}
\end{gathered}
$$

Utilizando estas expresiones y la información de múltiples bases de datos de mediciones in situ, Kahma y Calkoen (1992) y Hwang et al. (2011) definieron curvas empíricas para describir el crecimiento de la energía del oleaje local bajo condiciones atmosféricas estables. En el presente trabajo, se utilizaron estas curvas empíricas como referencia para calcular los valores de $\boldsymbol{E}_{\boldsymbol{S E A}}$ y $\boldsymbol{F}_{\boldsymbol{S E A}}$ en función de $\boldsymbol{X}$.

Los valores de $X$ utilizados para las ecuaciones (8-10) se calcularon trazando una línea recta entre el punto de estudio en el océano y la línea de costa de acuerdo con la dirección del viento. Para el cálculo de $\boldsymbol{E}_{S E A}, \boldsymbol{F}_{\text {SEA }}$ y $\boldsymbol{X}$ en los 25 nodos alrededor de la boya ASIS $\left(\sim 400 \mathrm{~km}^{2}\right)$, se supuso que el campo de viento era homogéneo y tenía las mismas 


\section{RESUlts}

The buoy-derived $U_{10}$ values ranged from 0 to $20 \mathrm{~m} \mathrm{~s}^{-1}$ (fig. 3a). Wind direction $(\theta)$ was mainly around $0^{\circ}$ (southerly winds) and $180^{\circ}$ (northerly winds, Tehuanos; fig. 3b). During the Tehuano wind events, $U_{10}$ values were as high as $20 \mathrm{~m} \mathrm{~s}^{-1}$, whereas $\theta$ remained approximately constant $\left(180^{\circ}\right)$.

The integral wave parameters obtained using the buoy measurements and $\mathrm{HF}$ radar calculations were in general strongly correlated (fig. 3c-f). The $H_{S}$ and $H_{S E A}$ (fig. 3c, d) values increased during the Tehuano wind events, especially on 4 and 9 March 2005. The $H_{S W E L L}$ values (fig. 3e) were relatively constant, between 0.5 and $1.1 \mathrm{~m}$. The $F_{S E A}$ values (fig. 3f) increased mainly during the Tehuano events. Some low $F_{S E A}$ values were observed, with frequencies close to $0.1 \mathrm{~Hz}$.

The frequency spectra measured and calculated at the ASIS buoy location associated with Tehuano events showed strong correlation at the energy levels (fig. 4a, b). The $f_{S}$ values (asterisks) are similar in both spectral groups. Comparisons of the energy values of the spectra measured and calculated as a function of frequency showed a suitable agreement for the $F_{S E A}$ values, with small significant differences in the energy values (data not presented).

In general, there was an adequate correlation $\left(R^{2}>0.5\right)$ among the $H_{S}, H_{S E A}, H_{S W E L L}$, and $F_{S E A}$ values associated with the measured and calculated frequency spectra (fig. 5). An underestimation was observed for the calculated $H_{S}$ values (fig. 5a), associated with a RMSE of $0.39 \mathrm{~m}$ and a positive bias of $0.19 \mathrm{~m}$. The $H_{S E A}$ values also showed this behavior (fig. 5b), with a RMSE of $0.36 \mathrm{~m}$ and positive bias of $0.1 \mathrm{~m}$. The $H_{\text {SWELL }}$ values (fig. 5c) showed a better correlation, with a RMSE of $0.24 \mathrm{~m}$ and bias of $0.15 \mathrm{~m}$, though a slight tendency to underestimate the radar-derived values persisted. A significant correlation was observed between the measured and calculated $F_{S E A}$ values (fig. 5d), the statistical error values indicating a slight tendency to overestimate the radar-derived values.

A suitable agreement was observed between the $\boldsymbol{E}_{\boldsymbol{S E A}}$ and $\boldsymbol{F}_{\text {SEA }}$ values, calculated based on the values obtained from the ASIS buoy measurements and those obtained from the HF radar estimates for the buoy location (fig. 6), relative to the empirical curves derived by Kahma and Calkoen (1992) and Hwang et al. (2011). In general, the $\boldsymbol{E}_{\boldsymbol{S E A} A}$ and $\boldsymbol{F}_{\boldsymbol{S E A}}$ values obtained from the measured and calculated data differed. In the case of $\boldsymbol{E}_{\boldsymbol{S E A}}$, there was high data scattering relative to the empirical curves (fig. 6a); however, the linear fit of the radarderived $\boldsymbol{E}_{\boldsymbol{S E A}}$ values showed a significant correlation with the empirical curves. In the case of $\boldsymbol{F}_{\boldsymbol{S E A}}$, there was small data scattering relative to the empirical curves and the linear fit showed a slight tendency to underestimate the values when $\boldsymbol{X}>2 \times 10^{3}$ (fig. 6b).

In the 25 cells near the ASIS buoy $\left(\sim 400 \mathrm{~km}^{2}\right)$, there was high scattering of the $\boldsymbol{E}_{S E A}$ values and small scattering of the condiciones de dirección y rapidez del viento medidas por la boya ASIS. Por lo tanto, usando los valores calculados de $E_{S E A}, F_{S E A}$ y $X$ y siguiendo la suposición de homogeneidad del viento en los 25 nodos, se calcularon los valores de $\boldsymbol{E}_{\boldsymbol{S E A}}$, $\boldsymbol{F}_{\boldsymbol{S E A}}$ y $\boldsymbol{X}$ de acuerdo con las ecuaciones (8-10).

Los valores de $\boldsymbol{E}_{\boldsymbol{S E A}}$ y $\boldsymbol{F}_{\boldsymbol{S E A}}$ en función de $\boldsymbol{X}$ se analizaron inicialmente con los valores obtenidos con las mediciones de la boya y los obtenidos con los datos del radar HF en el nodo de la boya. A los valores de $\boldsymbol{E}_{\boldsymbol{S E A}}$ y $\boldsymbol{F}_{\boldsymbol{S E A}}$ obtenidos con los datos del radar HF, se les realizó un ajuste lineal en función de $\boldsymbol{X}$. Por otro lado, se analizaron los valores de $\boldsymbol{E}_{\boldsymbol{S E A} \boldsymbol{A}}$ y $\boldsymbol{F}_{\boldsymbol{S E A}}$ en función de $\boldsymbol{X}$ correspondientes a los 25 nodos ubicados alrededor de la boya ASIS. En este análisis se incluyó el cálculo de los valores medios y las desviaciones estándar de $\boldsymbol{E}_{S E A}$ y $\boldsymbol{F}_{S E A}$, agrupados con respecto al dominio de $\boldsymbol{X}$ en una escala de $10^{2}$. Además, se utilizaron los valores discretos de $H_{\text {SWELL }}$ y wsf para estudiar la posible influencia del swell en el crecimiento del oleaje. Se usaron valores de $H_{\text {SWELL }}$ agrupados en intervalos de $0.15 \mathrm{~m}$ entre 0.5 y $1.1 \mathrm{~m}$, y valores de ws $f$ agrupados en intervalos de 0.1 entre 0.35 y 0.85 .

\section{RESULTADOS}

Los valores de $U_{10}$ medidos por la boya ASIS oscilaron entre 0 y $20 \mathrm{~m} \mathrm{~s}^{-1}$ (fig. 3a). La dirección del viento $(\theta)$ fue principalmente alrededor de $0^{\circ}$ (vientos del sur) y $180^{\circ}$ (vientos del norte, tehuanos; fig. 3b). Durante los eventos tehuanos, los valores de $U_{10}$ fueron de hasta $20 \mathrm{~m} \mathrm{~s}^{-1}$, mientras que $\theta$ se mantuvo aproximadamente constante $\left(180^{\circ}\right)$.

Los parámetros integrales del oleaje obtenidos de las mediciones de la boya y los calculados con información de radar $\mathrm{HF}$, en general, presentaron una alta correlación (fig. 3c-f). Los valores de $H_{S}$ y $H_{S E A}$ (fig. 3c, d) se incrementaron durante los eventos tehuanos, siendo notorio este incremento en los eventos del 4 y 9 de marzo de 2005. Los valores de $H_{\text {SWELL }}$ (fig. 3e) presentaron valores aproximadamente constantes, entre 0.5 y $1.1 \mathrm{~m}$. Los valores de $F_{S E A}$ (fig. $3 f$ ) se incrementaron principalmente durante los eventos tehuanos. Se observaron algunos valores bajos de $F_{S E A}$, con frecuencias cercanas a $0.1 \mathrm{~Hz}$.

Los espectros en frecuencia medidos y los calculados en el nodo de la boya ASIS asociados a eventos tehuanos mostraron una alta correlación en los niveles de energía (fig. 4a, b). Los valores de $f_{s}$ (asteriscos) fueron similares en los dos grupos de espectros. Las comparaciones de los valores de energía de los espectros medidos y calculados en función de la frecuencia mostraron una concordancia adecuada de los valores $F_{S E A}$, con diferencias en los valores de energía poco significativas (datos no presentados).

En general, se presentó una correlación adecuada $\left(R^{2}>0.5\right)$ entre los valores de $H_{S}, H_{\text {SEA }}, H_{\text {SWELL }}$ y $F_{S E A}$ asociados a los espectros en frecuencia medidos y calculados (fig. 5). Se observó una subestimación de los valores $H_{S}$ calculados con información de radar HF (fig. 5a), asociados a 


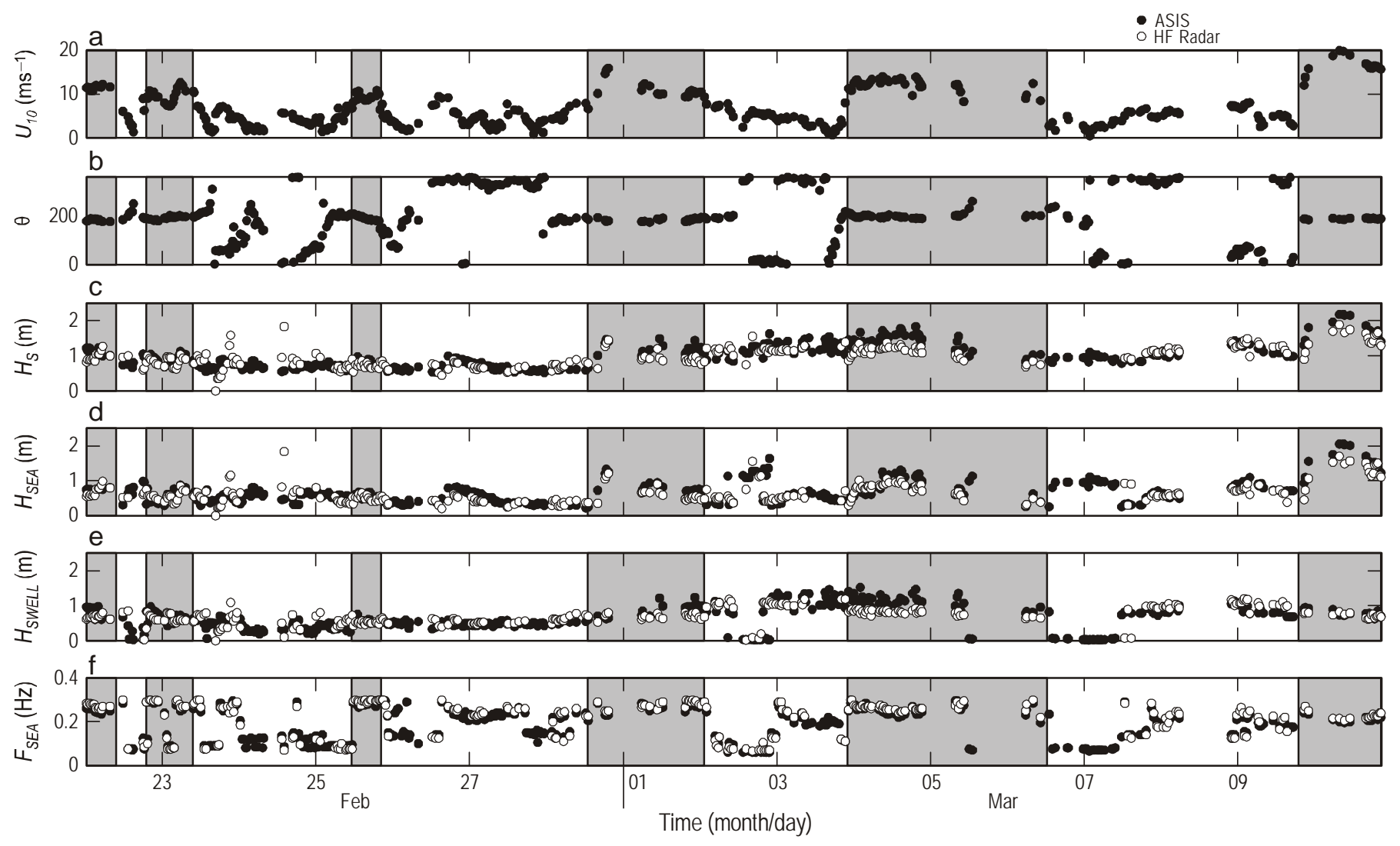

Figure 3. Time series for the period from 22 February to 10 March 2005 using wind and wave measurements from the ASIS buoy (filled circles) and wave calculations using high-frequency radars (empty circles). (a) Wind speed $\left(U_{10}\right)$. (b) Wind direction in degrees relative to the North $(\theta)$. (c) Significant wave height $\left(H_{S}\right)$. (d) Significant wave height of wind sea $\left(H_{S E A}\right)$. (e) Significant wave height of swell $\left(H_{S W E L L}\right)$. (f) Peak frequency of wind sea $\left(F_{S E A}\right)$. Gray blocks indicate periods of Tehuano wind events with values of $U_{10} \geq 8 \mathrm{~m} \mathrm{~s}^{-1}$ and $\theta \sim 180^{\circ}$.

Figura 3. Series de tiempo para el periodo del 22 de febrero al 10 de marzo de 2005 con mediciones del viento y oleaje de la boya ASIS (ć́rculos negros) y las estimaciones del oleaje mediante radares de alta frecuencia (círculos blancos). (a) Velocidad del viento ( $U_{10}$ ). (b) Dirección del viento en grados en relación al Norte $(\theta)$. (c) Altura significante del oleaje $\left(H_{S}\right)$. (d) Altura significante del oleaje local $\left(H_{S E A}\right)$. (e) Altura significante del swell $\left(H_{S W E L L}\right)$. (f) Frecuencia asociada al pico espectral del oleaje local $\left(F_{S E A}\right)$. Los bloques grises indican periodos de vientos Tehuanos con valores de $U_{10} \geq 8 \mathrm{~m} \mathrm{~s}^{-1}$ y $\theta \sim 180^{\circ}$.

$\boldsymbol{F}_{\text {SEA }}$ values relative to the empirical curves derived by Kahma and Calkoen (1992) and Hwang et al. (2011) (fig. 7). The $\boldsymbol{E}_{\boldsymbol{S E A}}$ values are the same in figure $7(\mathrm{a}, \mathrm{b})$ and the $\boldsymbol{F}_{\boldsymbol{S E A} \boldsymbol{A}}$ values are the same in figure $7(\mathrm{c}, \mathrm{d})$; however, the bin color scale corresponds to discrete $H_{S W E L L}$ and wsf values. The mean $\boldsymbol{E}_{\boldsymbol{S E A}}$ values are close to the empirical curves from Kahma and Calkoen (1992) and Hwang et al. (2011), and are below the curves only at $\boldsymbol{X}>2.5 \times 10^{3}$. In general, the standard deviation (error bars) associated with the mean $\boldsymbol{E}_{\boldsymbol{S E A}}$ values was similar for all the range of $\boldsymbol{X}$ values. The mean $\boldsymbol{F}_{\boldsymbol{S E A}}$ values were close to the empirical curves, with similar error bars for all the range of $\boldsymbol{X}$ values and lower relative to $\boldsymbol{E}_{S E A}$.

The $H_{\text {SWELL }}$ values were randomly scattered around the empirical curves (fig. 7a, c), whereas the wsf values were distributed as a function of $\boldsymbol{X}$ (fig. 7b, d). In the case of $H_{S W E L L}$, for a range of $60 \mathrm{~cm}$, the $\boldsymbol{E}_{\text {SEA }}$ values of $\sim 0.6 \mathrm{~m}$ were located mainly below the empirical curves, whereas the other values un RMSE de $0.39 \mathrm{~m}$ y un sesgo positivo de $0.19 \mathrm{~m}$. Lo mismo se observó para los valores de $H_{S E A}$ (fig. 5b), con un RMSE de $0.36 \mathrm{~m}$ y un sesgo positivo de $0.1 \mathrm{~m}$. Los valores de $H_{S W E L L}$ (fig. 5c) mostraron una mejor correlación, con un RMSE de $0.24 \mathrm{~m}$ y un sesgo positivo de $0.15 \mathrm{~m}$, aunque se mantuvo ligeramente la tendencia a subestimar los valores calculados con información de radar HF. Se observó una correlación significativa entre los valores medidos y calculados de $F_{S E A}$ (fig. 5d), con valores de los errores estadísticos que sugieren una ligera tendencia a sobreestimar los valores calculados con información de radar HF.

Se observó una concordancia adecuada entre los valores de $\boldsymbol{E}_{\text {SEA }}$ y $\boldsymbol{F}_{\text {SEA }}$, calculados a partir de los valores obtenidos con las mediciones de la boya ASIS y los obtenidos con los datos de radar HF en el nodo de la boya (fig. 6), con respecto a las curvas empíricas de Kahma y Calkoen (1992) y Hwang et al. (2011). En general, los valores de $\boldsymbol{E}_{\text {SEA }}$ y $\boldsymbol{F}_{\text {SEA }}$ determinados con la información medida y calculada no presentaron 


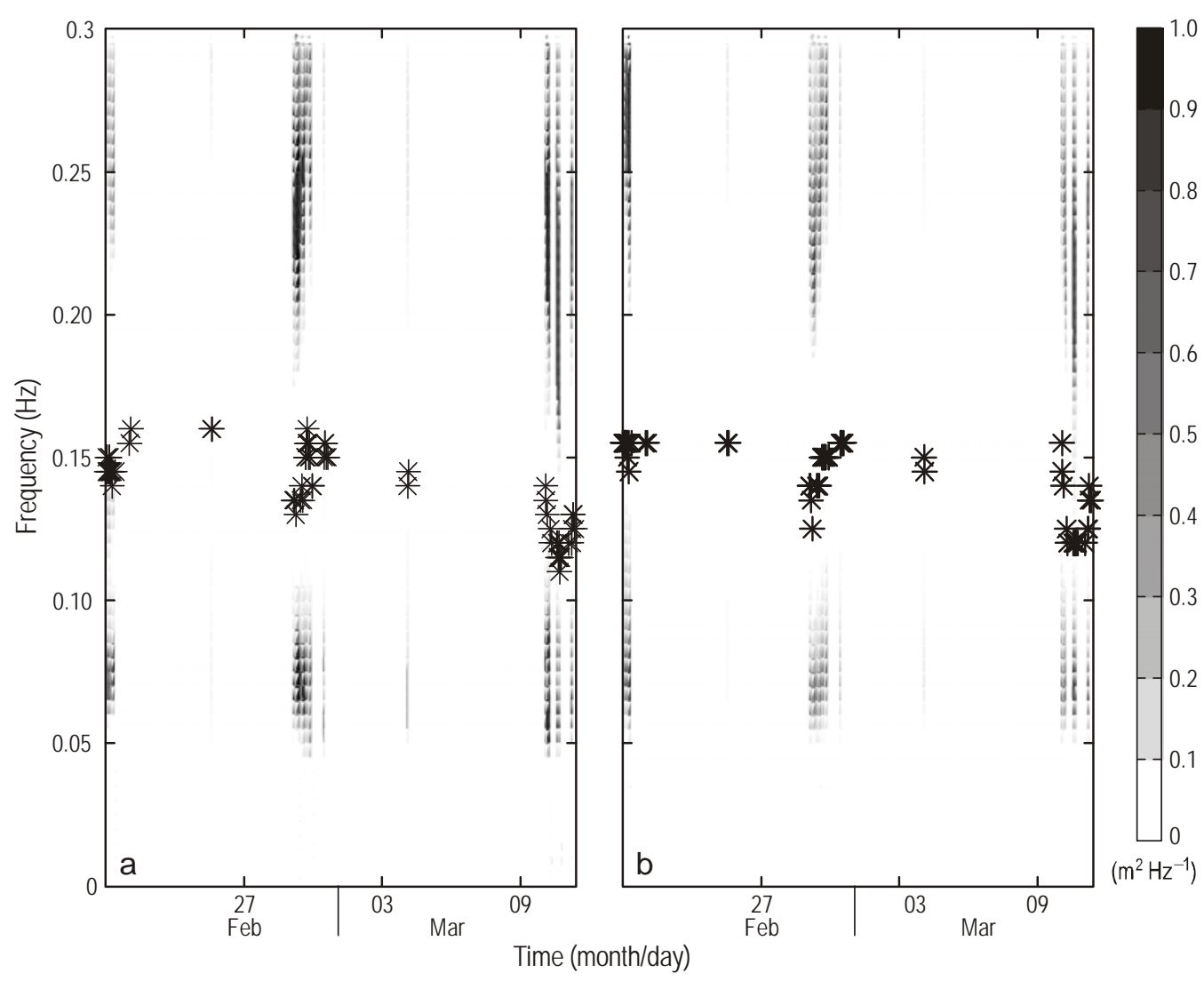

Figure 4. Frequency spectra for the period from 22 February to 10 March 2005 selected from wind information $\left(U_{10} \geq 8 \mathrm{~m} \mathrm{~s}{ }^{-1}\right.$ and northerly winds; see gray blocks in fig. 3): (a) measured by the ASIS buoy; (b) calculated from high-frequency radar using the empirical function $\alpha_{F}$ as a function of $U_{10}$. The black asterisks correspond to the separation frequency $\left(f_{S}\right)$ calculated using the method proposed by Hwang et al. (2012).

Figura 4. Espectros de frecuencia para el periodo del 22 de febrero al 10 de marzo de 2005 seleccionados a partir de información del viento ( $U_{10} \geq 8 \mathrm{~m} \mathrm{~s}^{-1}$ y vientos del norte; ver las secciones grises en fig. 3): (a) medidos por la boya ASIS; (b) calculados a partir de radares de alta frecuencia usando la función empírica $\alpha_{F}$ en función de $U_{10}$. Los asteriscos negros corresponden a la frecuencia de separación $\left(f_{S}\right)$ calculada mediante el método de Hwang et al. (2012).

were scattered around the curves. The wsf values ranging from 0.5 to 0.85 (high $E_{\text {SEA }}$ values relative to $E_{\text {TOT }}$ ) were mainly associated with values of $\boldsymbol{X}<10^{3}$, whereas those $\leq 0.5$ (low $E_{S E A}$ values relative to $E_{T O T}$ ) were associated with values of $\boldsymbol{X} \geq 10^{3}$.

\section{DISCUSSION}

Information on wind sea and swell can typically be found in wave spectra. $E_{S W E L L}$ and $E_{S E A}$ are generally identified by analysis of the directional spectrum, calculating the area of the spectrum that is modified by the wind and associated with $E_{S E A}$ (Hanson and Phillips 2001, Tracy et al. 2007). Based on a frequency spectrum $\left(S_{F}\right)$, Hwang et al. (2012) defined a frequency $\left(f_{S}\right)$ that can separate $E_{S W E L L}$ and $E_{S E A}$; to calculate $f_{S}$, these authors performed a generalization of the wave slope function used by the NOAA's National Data Buoy Center. This function calculates wave slope as a product of $H_{S}$ and its los mismos valores. En el caso de $\boldsymbol{E}_{S E A}$, la dispersión de los datos con relación a las curvas empíricas fue alta (fig. 6a); sin embargo, el ajuste lineal de los valores de $\boldsymbol{E}_{\text {SEA }}$ calculados con información de radar HF presentó una correlación significativa con las curvas empíricas. En el caso de $\boldsymbol{F}_{\text {SEA }}$, la dispersión de los datos con relación a las curvas empíricas fue baja y el ajuste lineal mostró una ligera tendencia a subestimar los valores cuando $\boldsymbol{X}>2 \times 10^{3}$ (fig. 6b).

En los 25 nodos alrededor de la boya ASIS $\left(\sim 400 \mathrm{~km}^{2}\right)$, se observó una alta dispersión de los valores de $\boldsymbol{E}_{\text {SEA }} \mathrm{y}$ una baja dispersión de los valores $\boldsymbol{F}_{S E A}$ con relación a las curvas empíricas de Kahma y Calkoen (1992) y Hwang et al. (2011) (fig. 7). Los valores de $\boldsymbol{E}_{S E A}$ son los mismos en la figura $7(\mathrm{a}, \mathrm{b})$ y los valores de $\boldsymbol{F}_{S E A}$ son los mismos en la figura 7(c, d); sin embargo, la escala de colores de los puntos corresponde a valores discretos de $H_{S W E L L} \mathrm{y}$ wsf. Los valores medios de $\boldsymbol{E}_{S E A}$ están cercanos a las curvas de Kahma y Calkoen (1992) y Hwang et al. (2011), y están por debajo de 

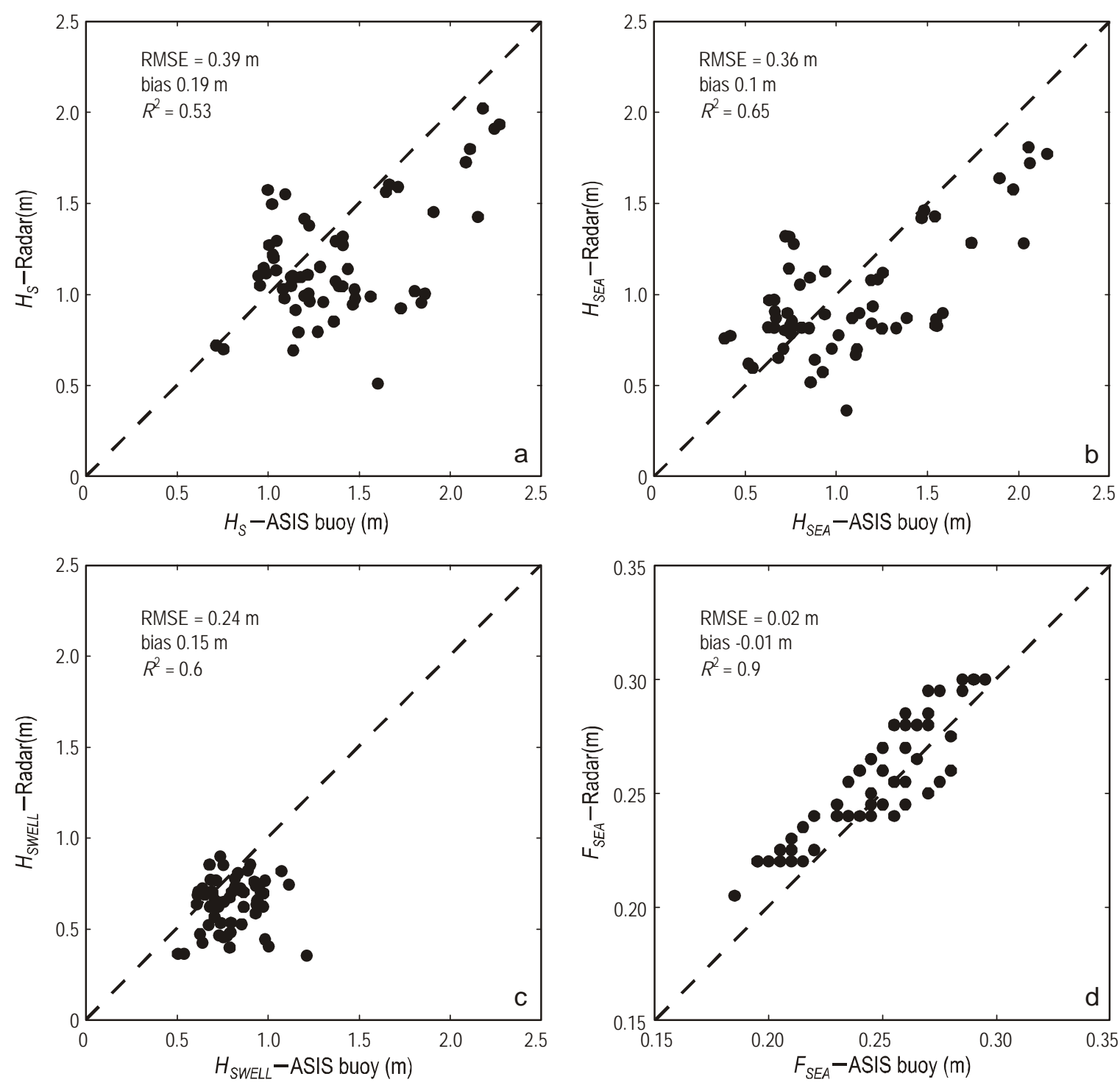

Figure 5. Scatter plots using the ASIS buoy measurements and the high-frequency radar calculations at the buoy location: (a) $H_{S}$, significant wave height; (b) $H_{S E A}$, significant wave height of wind sea; (c) $H_{S W E L L}$, significant wave height of swell; (d) $F_{S E A}$, peak frequency of wind sea. These variables were calculated from the frequency spectra shown in figure 4. RMSE, root mean square error; $R^{2}$, correlation coefficient.

Figura 5. Gráficas de dispersión con las mediciones de la boya ASIS y las mediciones del radar de alta frecuencia en el sitio de anclaje de la boya ASIS: (a) $H_{S}$, altura significante del oleaje; (b) $H_{S E A}$, altura significante del oleaje local; (c) $H_{S W E L L}$, altura significante del $s w e l l$; (d) $F_{S E A}$, frecuencia asociada al pico espectral del oleaje local. Estas variables se calcularon a partir de los espectros de frecuencia mostrados en la figura 4. RMSE, error cuadrático medio; $R^{2}$, coeficiente de correlación.

associated wavenumber as a function of the spectral moments. Hwang et al. (2012) propose a spectral integration function $\left(I_{1}\right)$ modifying the wave slope function, where $S_{F}$ is replaced by the ratio $S_{F}$ to frequency vector; $f_{S}$ is calcuated as the frequency associated with the maximum value of $I_{1}$. Other methods include spectral analyses that allow the identification of energy values associated with low $\left(E_{\text {SWELL }}\right)$ and high $\left(E_{S E A}\right)$ frequencies through spectral decomposition (e.g., Hilbert-Huang transform). In the present study, we used the method proposed by Hwang et al. (2012) because it is based on physical concepts of wave behavior and is widely used. las curvas empíricas sólo cuando $\boldsymbol{X}>2.5 \times 10^{3}$. En general, las desviaciones estándar (barras de error) asociadas a los valores medios de $\boldsymbol{E}_{S E A}$ fueron similares para todo el intervalo de valores de $\boldsymbol{X}$. En el caso de $\boldsymbol{F}_{\boldsymbol{S E A}}$, los valores medios presentaron valores cercanos a las curvas empíricas, con barras de error similares para todo el intervalo de valores de $\boldsymbol{X}$ y menores respecto a $\boldsymbol{E}_{S E A}$.

La distribución de los valores de $H_{S W E L L}$ alrededor de las curvas empíricas fue aleatorio (fig. 7a, c), mientras que los valores de wsf presentaron una distribución en función de $\boldsymbol{X}$ (fig. $7 \mathrm{~b}, \mathrm{~d}$ ). En el caso de $H_{S W E L L}$, para un intervalo de $60 \mathrm{~cm}$, 

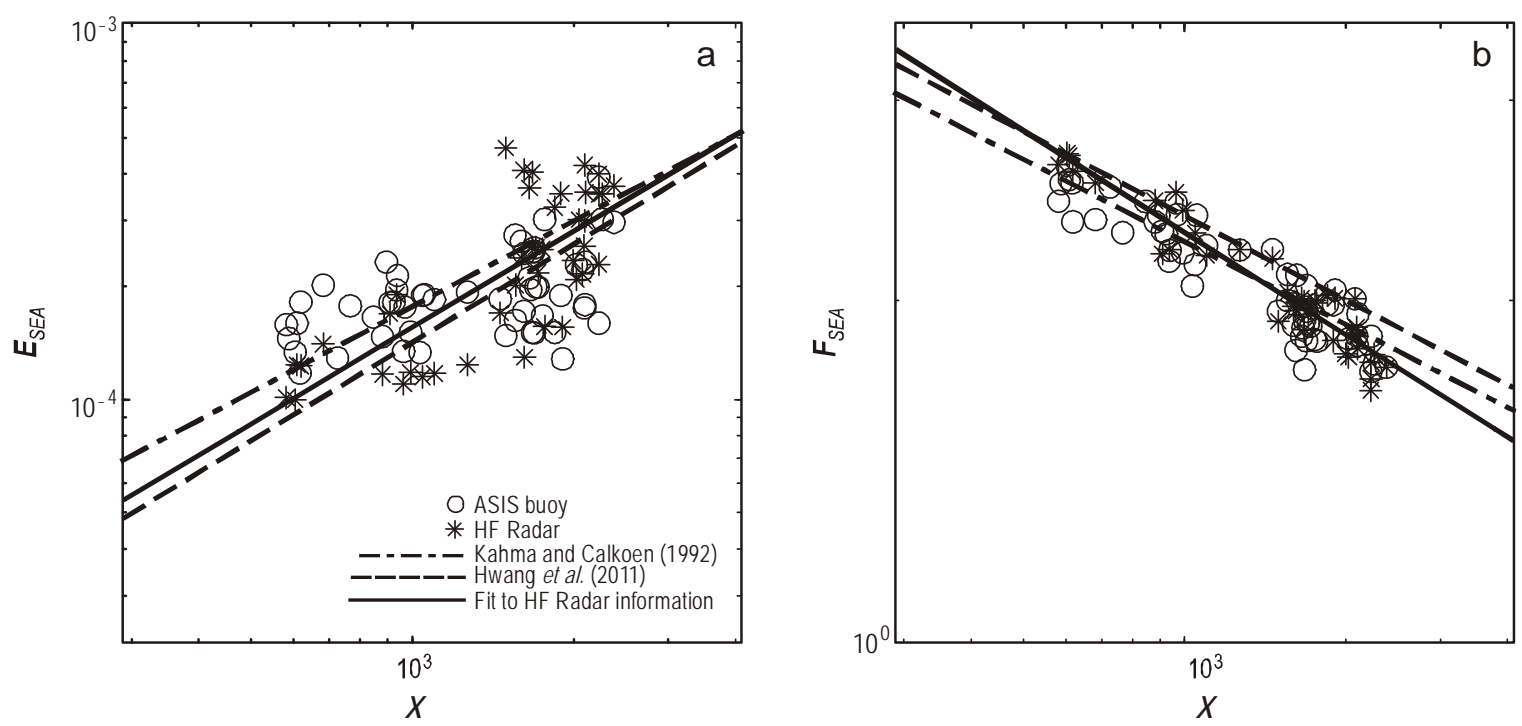

Figure 6. Values of (a) dimensionless wave energy $\left(\boldsymbol{E}_{\boldsymbol{S E A}}\right)$ and (b) dimensionless peak frequency $\left(\boldsymbol{F}_{\boldsymbol{S E A}}\right)$ as a function of dimensionless fetch $(\boldsymbol{X})$ at the ASIS buoy location. The circles and asterisks correspond to ASIS buoy measurements and high-frequency radar measurements, respectively. The dashed and dot-dashed lines correspond to growth curves derived by Hwang et al. (2011) and Kahma and Calkoen (1992), respectively, for stable conditions. The solid black line corresponds to the fit to the growth values from the radar measurements.

Figura 6. Valores de (a) la energía adimensional del oleaje $\left(\boldsymbol{E}_{\boldsymbol{S E A}}\right)$ y (b) la frecuencia adimensional asociada al pico espectral ( $\left.\boldsymbol{F}_{\boldsymbol{S E A}}\right)$ en función del fetch adimensional $(\boldsymbol{X})$ en el sitio de anclaje de la boya ASIS. Los círculos y asteriscos corresponden a las mediciones de la boya ASIS y las mediciones del radar de alta frecuencia, respectivamente. La línea discontinua y la línea discontinua con puntos corresponden a las curvas de crecimiento de Hwang et al. (2011) y Kahma y Calkoen (1992), respectivamente, para condiciones estables. La línea sólida corresponde al ajuste a los valores de crecimiento de las mediciones del radar.

\section{Comparison of the $\boldsymbol{H}_{S}, \boldsymbol{H}_{S E A}, \boldsymbol{H}_{S W E L L}$, and $\boldsymbol{F}_{S E A}$ values}

The differences found between the measured and calculated values of $H_{S}, H_{S E A}, H_{S W E L L}$, and $F_{S E A}$ can be attributed to errors in the estimation of the radar-derived frequency spectrum using a linear parametric model. Toro (2014) indicate that a potential source of error could be the dependence of parameter $\alpha_{F}$ on other variables not considered in the estimation (e.g., wave direction). Gurgel et al. (2006) and Toro (2014) suggest that the errors in the wave calculations are due to the use of only one HF radar station. Wyatt (1989) attributes the errors primarily to the direction of wave propagation perpendicular to the direction of the radar measurement. The characteristics of the INTOA data set used in this study coincide with the conditions proposed by Wyatt (1989), Gurgel et al. (2006), and Toro (2014). These characteristics of the data set could increase the errors in the wave calculations.

The estimated $H_{\text {SWELL }}$ values ranged from 0.5 to $1.1 \mathrm{~m}$ and coincide with those reported by García-Nava et al. (2009); however, the low value of $R^{2}(0.6)$ suggests that the linear parametric model used here does not adequately resolve the swell dispersion. In the temporal evolution of the spectrum, this dispersion is observed as a shift from lower to higher frequencies of the spectral peak (see fig. 4 in Ocampo-Torres et al. 2011). Conversely, the spectra calculated using HF los valores de $\boldsymbol{E}_{\text {SEA }}$ de $\sim 0.6 \mathrm{~m}$ se ubicaron principalmente por debajo de las curvas empíricas, mientras que los demás valores del intervalo se encontraron dispersos alrededor de las curvas. Los valores de wsf entre 0.5 y 0.85 (valores altos de $E_{S E A}$ respecto a $E_{T O T}$ ) estuvieron asociados principalmente a los valores de $\boldsymbol{X}<10^{3}$, mientras que los valores de ws $\leq \leq 0.5$ (valores bajos de $E_{S E A}$ respecto a $E_{T O T}$ ) estuvieron asociados a los valores de $\boldsymbol{X} \geq 10^{3}$.

\section{Discusión}

En un espectro del oleaje es común encontrar información de la energía asociada al swell y al oleaje local. La identificación de $E_{S W E L L}$ y $E_{S E A}$ se realiza por medio del análisis del espectro direccional, calculando el área del espectro modificada por el viento y asociada con $E_{\text {SEA }}$ (Hanson y Phillips 2001, Tracy et al. 2007). A partir del espectro en frecuencia $\left(S_{F}\right)$, Hwang et al. (2012) definieron una frecuencia $\left(f_{s}\right)$ que permite separar $E_{S W E L L}$ y $E_{S E A}$; para calcular $f_{S}$, estos autores hacen una generalización de la función pendiente de la ola usada operacionalmente por la National Data Buoy Center de la NOAA. Esta función calcula la pendiente de la ola como el producto de $H_{S}$ y su número de onda asociado en función de los momentos del espectro. Hwang et al. (2012) proponen una función de integración espectral $\left(I_{1}\right)$ modificando la función pendiente de la ola, donde $S_{F}$ se reemplaza por la 

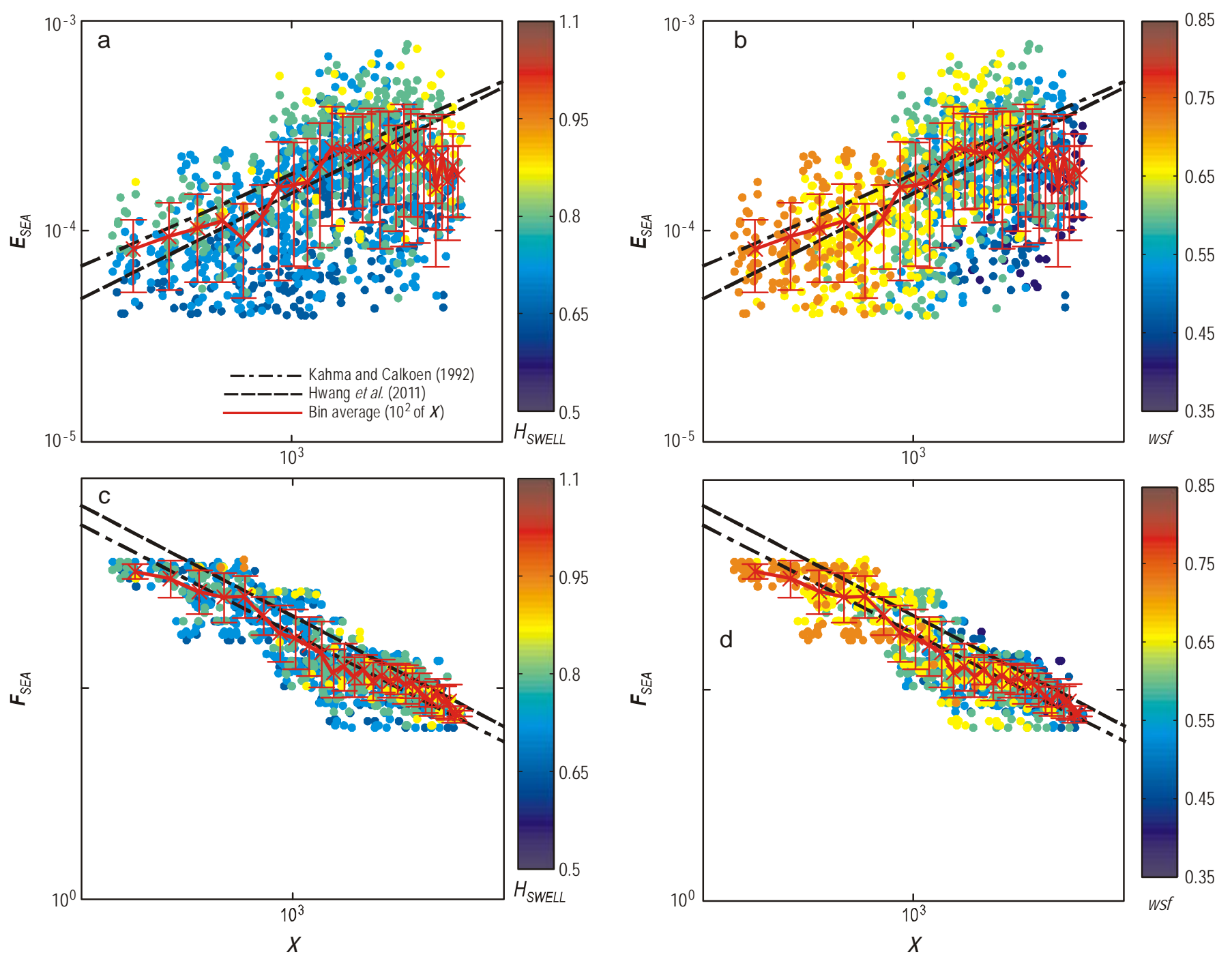

Figure 7. (a), (b) Dimensionless wave energy $\left(\boldsymbol{E}_{\boldsymbol{S E A}}\right)$ and $(\mathbf{c}),(\mathbf{d})$ dimensionaless peak frequency $\left(\boldsymbol{F}_{\boldsymbol{S E A}}\right)$ as a function of dimensionless fetch $(\boldsymbol{X})$ in the $\sim 400 \mathrm{~km}^{2}$ (denoted by the 25 cells in the vicinity of the moored ASIS buoy). The dashed and dot-dashed lines correspond to growth curves derived by Hwang et al. (2011) and Kahma and Calkoen (1992), respectively, for stable conditions. The solid red lines and the error bars correspond to the mean values and the standard deviations of $\boldsymbol{X}$ bins at $10^{2}$ intervals. Color scale: (a), (c) significant wave height of swell $\left(H_{S W E L L}\right)$ bins at $0.15 \mathrm{~m}$ intervals; (b), (d) wind-sea fraction (wsf) bins at 0.1 intervals.

Figura 7. (a), (b) Energía adimensional del oleaje $\left(\boldsymbol{E}_{\boldsymbol{S E A}}\right)$ y (c), (d) frecuencia adimensional asociada al pico espectral ( $\left.\boldsymbol{F}_{\boldsymbol{S E A}}\right)$ en función del fetch admimensional $(\boldsymbol{X})$ en $\sim 400 \mathrm{~km}^{2}$ (correspondiente a 25 nodos alrededor del sitio de anclaje de la boya ASIS). La línea discontinua y la línea discontinua con puntos corresponden a las curvas de crecimiento de Hwang et al. (2011) y Kahma y Calkoen (1992), respectivamente, para condiciones estables. Las líneas rojas y las barras de error corresponden a los valores medios y las desviaciones estándar de los puntos de $\boldsymbol{X}$ a intervalos de $10^{2}$. Escala de color: (a), (c) altura significante del swell $\left(H_{\text {SWELL }}\right)$ a intervalos de 0.15 m; (b), (d) fracción de la energía correspondiente al oleaje local ( $w s f)$ a intervalos de 0.1 .

radar information maintained, for the most part, a similar value of the swell peak frequency. Nonetheless, in the radarderived spectra it was possible to reproduce the shape and energy level of the peaks in the measured spectra. The $F_{\text {SEA }}$ values close to $0.1 \mathrm{~Hz}$ can be related to non-Tehuano wind events. In these cases, since the spectral energy in the $E_{S E A}$ frequency range is low, the $F_{S E A}$ value found is close to the $f_{S}$ value calculated with the method proposed by Hwang et al. (2011). razón entre $S_{F}$ y el vector de frecuencias; $f_{S}$ se calcula como la frecuencia asociada al valor máximo de la función $I_{1}$. Otros métodos contemplan análisis espectrales que permiten identificar los valores de energía asociados a las bajas $\left(E_{\text {SWELL }}\right)$ y altas $\left(E_{S E A}\right)$ frecuencias por medio de la descomposición de la señal del espectro (e.g., transformada de Hilbert-Huang). En este trabajo, se utilizó el método de Hwang et al. (2012) porque está basado en conceptos físicos del comportamiento del oleaje y es un método ampliamente usado. 
Despite the differences found between the measured and calculated values, the suitable agreement of the time series and relatively low values of the statistical errors suggest that the linear parametric model and, in particular, the parameter $\alpha_{F}$, which is a function of $U_{10}$, can be used to obtain a wave frequency spectrum from HF radar data.

\section{Wave growth at the ASIS buoy location and nearby cells}

Comparisons of the $\boldsymbol{E}_{S E A}$ and $\boldsymbol{F}_{S E A}$ values estimated as a function of $\boldsymbol{X}$ were made based on the empirical curves derived by Kahma and Calkoen (1992) and Hwang et al. (2011). These curves are currently the main reference in the calculation of these values and are necessary for numerical wave models since they are used to validate fetch-limited wave growth (Bottema and van Vledder 2009). In the present study, the wave growth values were in general close to the empirical curves. The values analyzed in this study cover the range $350<\boldsymbol{X}<2500$, coinciding with most of the works consulted.

The dispersion of the radar-derived $\boldsymbol{E}_{S E A}$ and $\boldsymbol{F}_{S E A}$ data relative to the empirical curves can be associated with potential sources of error in the calculation of the frequency spectrum. The buoy-derived $\boldsymbol{E}_{S E A}$ and $\boldsymbol{F}_{S E A}$ values, however, also showed certain dispersion. Kahma and Calkoen (1992), Ebuchi (1999), and Bottema and van Vledder (2008) suggest that some dispersion occurs because wave growth analyses using in situ data do not strictly comply with controlled wind and fetch conditions. Likewise, Young and Verhagen (1996) indicate that dispersion is characteristic of in situ data analyses and that it is due to causes such as sampling variability and instrument accuracy. Ardhuin et al. (2007) associate the dispersion of wave growth data relative to the empirical curves with the variability of the wind, the development of the atmospheric boundary layer, and the presence of strong tidal currents. Walsh et al. (1989) and Ardhuin et al. (2007) attribute some of the dispersion of the data to the presence of a slanting fetch. Romero and Melville (2010) and Hwang et al. (2011) show that the dispersion of the INTOA experiment data is similar to that obtained with other data bases, such as that of Kahma and Calkoen (1992) for waves generated under stable conditions.

In this study, wave growth was analyzed using in situ measurements and one of the assumptions was homogeneous wind conditions in the study area $\left(\sim 400 \mathrm{~km}^{2}\right)$. Hwang et al. (2011) analyzed INTOA data and indicated that dispersion of the data relative to the empirical curves could have been caused by the nonhomogeneous wind fields generated during Tehuano events and the presence of swell that propagates against the locally generated waves. Tehuano wind events are clearly differentiated (Hwang et al. 2011) because they are characterized by approximately constant wind direction $(\theta)$ values (from the north) and high $U_{10}$ values $\left(\geq 8 \mathrm{~m} \mathrm{~s}^{-1}\right)$. Thus, taking into account the suggestions made by diverse authors and the conditions of the INTOA experiment, the possible

\section{Comparación de los valores de $\boldsymbol{H}_{S}, \boldsymbol{H}_{S E A}, \boldsymbol{H}_{S W E L L}$ y $\boldsymbol{F}_{S E A}$}

Las diferencias encontradas en la comparación de valores medidos y calculados de $H_{S}, H_{S E A}, H_{S W E L L}$ y $F_{S E A}$ se pueden asociar a errores en el cálculo del espectro en frecuencia obtenido por medio de información de radar HF usando el modelo paramétrico lineal. Toro (2014) sugiere como fuente potencial de error la dependencia del parámetro $\alpha_{F}$ a otras variables no consideradas en su cálculo (e.g., la dirección del oleaje). Gurgel et al. (2006) y Toro (2014) proponen que los errores en el cálculo de la información del oleaje se deben al uso de una sola estación de radar HF. Wyatt (1989) sugiere que la principal razón de los errores es la dirección de propagación del oleaje perpendicular a la dirección de medición del radar. Las características del set de datos del experimento INTOA utilizado en este trabajo coinciden con las condiciones propuestas por Wyatt (1989), Gurgel et al. (2006) y Toro (2014). Estas características del set de datos podrían incrementar los errores en los cálculos de información del oleaje.

Las valores de $H_{S W E L L}$ variaron entre 0.5 y $1.1 \mathrm{~m}$ y están en concordancia con los valores registrados por García-Nava et al. (2009); sin embargo, el valor bajo de $R^{2}(0.6)$ sugiere que el modelo paramétrico lineal utilizado en este trabajo no resuelve de manera adecuada la dispersión del swell. Esta dispersión se observa, en la evolución temporal del espectro, como un corrimiento del pico espectral de bajas a altas frecuencias (ver fig. 4 en Ocampo-Torres et al. 2011). Por el contrario, los espectros calculados con información de radar HF mantuvieron, la mayoría de las veces, un valor similar de la frecuencia asociada al pico del espectro del swell. No obstante, la forma y el nivel energético de los picos en los espectros medidos se lograron reproducir en los espectros calculados con los radares HF. Los valores de $F_{S E A}$ cercanos a $0.1 \mathrm{~Hz}$ se pueden relacionar con eventos no tehuanos. En estos casos, debido a que la energía del espectro en el intervalo de frecuencias de $E_{S E A}$ es baja, el valor de $F_{S E A}$ encontrado es cercano al valor de $f_{S}$ calculado con el método de Hwang et al. (2011).

A pesar de las diferencias encontradas entre los valores medidos y los calculados, la concordancia adecuada de las series de tiempo y los valores bajos de los errores estadísticos sugieren que el modelo paramétrico lineal y, particularmente, el parámetro $\alpha_{F}$, que es función de $U_{10}$, pueden utilizarse para obtener el espectro en frecuencia del oleaje por medio de información obtenida con radares HF.

\section{Crecimiento del oleaje observado en el nodo de la boya ASIS y en los nodos cercanos}

Las comparaciones de los valores de $\boldsymbol{E}_{S E A}$ y $\boldsymbol{F}_{S E A}$ calculados en función de $\boldsymbol{X}$ se realizaron con base en las curvas empíricas de Kahma y Calkoen (1992) y Hwang et al. (2011). Estas curvas son, en la actualidad, el referente principal en el cálculo de estos valores y son fundamentales para los modelos numéricos de oleaje ya que son usadas para validar 
causes of the dispersion of the data relative to the empirical curves are as follows: errors in the calculation of the wave frequency spectra using HF radar data, calculation of the fetch defined by linear approximation using wind direction, the assumption of a homogeneous wind field, and the presence of swell.

The possible effect of swell on the $\boldsymbol{E}_{\text {SEA }}$ and $\boldsymbol{F}_{\text {SEA }}$ values was analyzed using associated $H_{S W E L L}$ and wsf values. The variables $H_{S W E L L}$ and wsf can be considered similar; however, the $H_{S W E L L}$ values are independent of wind sea and wind, whereas wsf indirectly quantifies the $H_{\text {SWELL }}$ values. The results obtained with these two variables show clear differences. The near-random distribution of the $H_{S W E L L}$ values relative to the empirical curves suggests that in this case it is the $E_{S E A}$ values that vary significantly. The presence of $H_{S W E L L}$ values of $\sim 0.6 \mathrm{~m}$ below the empirical curves could be related to errors in the calculation of the frequency spectrum. On the other hand, factor wsf represents the variation of $E_{S E A}$ relative to $E_{\text {TOT }}$ and in this study, the wsf values were clearly related to $\boldsymbol{X}$. Since $X$ values vary to a lesser extent than $U_{10}{ }^{2}$ and since $\boldsymbol{X}$ is inversely proportional to $U_{10}{ }^{2}$, the wsf values between 0.5 and 0.85 associated with $\boldsymbol{X}<10^{3}$ are clearly influenced by high wind values. Likewise, wsf values of $\leq 0.5$ associated with $\boldsymbol{X} \geq 10^{3}$ are related to low wind values. The behavior of the $H_{S W E L L}$ and wsf values used in this study relative to the empirical curves did not provide clear evidence to be able to define the effect of swell on wave growth.

The possible effect of swell on wave growth can also be analyzed based on the behavior of the linear fits and the mean estimated values. In the first case, the linear fits of the $\boldsymbol{E}_{\text {SEA }}$ and $\boldsymbol{F}_{S E A}$ values were significantly correlated with the HF radar data and the empirical curves derived by Kahma and Calkoen (1992) and Hwang et al. (2011); hence, the linear fits do not indicate any effect of swell on wave growth. Likewise, the mean $\boldsymbol{E}_{\text {SEA }}$ and $\boldsymbol{F}_{\text {SEA }}$ values estimated from information for the 25 cells in the vicinity of the ASIS buoy were close to the empirical curves. Values below the empirical curve were observed only in the case of $\boldsymbol{E}_{S E A}$ when $\boldsymbol{X}>2.5 \times 10^{3}$, which could represent slight evidence of the effect of swell on wave growth.

The effect of swell on wave growth has been well studied. Laboratory experiments (Mitsuyasu 1966, Donelan 1987) have shown that the presence of large waves drastically reduces wave growth. Kahma and Calkoen (1992) assumed that $E_{\text {SWELL }}$ was responsible for dispersion of the data in their analysis of wave growth; however, though their results do not show significant changes in $E_{S E A}$ due to $H_{S W E L L}$, they suggest that swell with pronounced slopes may affect wave growth. Conversely, Ardhuin et al. (2007), using in situ data and numerical models, found that moderate $E_{\text {SWELL }}$ values unlike wind sea do not significantly affect fetch-limited wave growth. García-Nava et al. (2012) suggest that the presence of swell attenuates short waves but consider that the effect on wave growth is in general insignificant. In the present study el crecimiento del oleaje limitado por el fetch (Bottema y van Vledder 2009). En este trabajo, los valores asociados al crecimiento del oleaje estuvieron, en general, cercanos a las curvas empíricas. Los valores analizados en este estudio cubren un intervalo de $350<\boldsymbol{X}<2500$, que coincide con la mayoría de los trabajos estudiados.

La dispersión de los valores de $\boldsymbol{E}_{S E A}$ y $\boldsymbol{F}_{S E A}$ calculados con información de radar HF respecto a las curvas empíricas podría asociarse a las fuentes potenciales de error relacionadas con el cálculo del espectro en frecuencia. Sin embargo, los valores de $\boldsymbol{E}_{\text {SEA }}$ y $\boldsymbol{F}_{\text {SEA }}$ calculados con los datos de la boya ASIS también presentaron cierto grado de dispersión. Kahma y Calkoen (1992), Ebuchi (1999) y Bottema y van Vledder (2008) sugieren que parte de la dispersión se debe a que el análisis del crecimiento del oleaje realizado con datos in situ no cumple estrictamente con condiciones controladas de viento y fetch. De igual manera, Young y Verhagen (1996) sugieren que la dispersión es propia del análisis de datos in situ y que se debe a causas tales como la variabilidad estadística del muestreo y la precisión instrumental. Ardhuin et al. (2007) asocian la dispersión de los valores del crecimiento del oleaje respecto a las curvas empíricas con la variabilidad del viento, el desarrollo de la capa límite atmosférica y la presencia de corrientes fuertes de marea. Walsh et al. (1989) y Ardhuin et al. (2007) atribuyen parte de la dispersión de los datos a la existencia de un fetch oblicuo (slanting fetch). Romero y Melville (2010) y Hwang et al. (2011) muestran que la dispersión de los datos del experimento INTOA es similar a la obtenida con otras bases de datos, como la de Kahma y Calkoen (1992) para olas generadas bajo condiciones estables.

En este trabajo se analizó el crecimiento del oleaje estimado a partir de datos medidos in situ. Una de las suposiciones era que el viento en el área de estudio $\left(\sim 400 \mathrm{~km}^{2}\right)$ era homogéneo. Hwang et al. (2011) analizaron los datos de INTOA y demostraron que las posibles causas de la dispersión de los datos respecto a las curvas empíricas eran los campos de viento no homogéneos producidos durante los eventos tehuanos y la presencia del swell que se propaga en contra del oleaje local. Los tehuanos son eventos claramente diferenciables (Hwang et al. 2011) porque se pueden caracterizar mediante valores aproximadamente constantes de la dirección del viento $\left(\theta\right.$, del norte) y valores altos de $U_{10}$ $\left(\geq 8 \mathrm{~m} \mathrm{~s}^{-1}\right.$ ). De acuerdo con lo sugerido por diversos autores y tomando en cuenta las condiciones del experimento INTOA, las posibles causas de la dispersión de los datos respecto a las curvas empíricas son las siguientes: los errores en el cálculo del espectro en frecuencia del oleaje mediante información obtenida de radar HF, el cálculo del fetch definido mediante una aproximación lineal utilizando la dirección del viento, las suposiciones del campo de viento homogéneo y la presencia del swell.

La posible influencia del swell en los valores de $\boldsymbol{E}_{\text {SEA }}$ y $\boldsymbol{F}_{S E A}$ se analizó utilizando valores asociados de $H_{S W E L L}$ y wSf. Las variables $H_{S W E L L}$ y wsf podrían considerarse similares; 
we did not find clear evidence of a possible effect of swell on wave growth.

In this paper we report $\boldsymbol{E}_{S E A}$ and $\boldsymbol{F}_{S E A}$ values as a function of $\boldsymbol{X}$ associated with wave growth close to the empirical curves derived by Kahma and Calkoen (1992) and Hwang et al. (2011). The growth values showed nonsignificant dispersion around the curves. This study is one of the first to analyze wave growth using HF radar data. The radar-derived wave spectrum showed a significant correlation with the in situ measurements. Our findings suggest that suitable wave data can be obtained by the novel method used to process high spatial and temporal resolution measurements with HF radars and a linear parametric model dependent on wind speed.

\section{ACKNOWLEDGMENTS}

This study was supported by the National Council for Science and Technology (CONACYT, Mexico, projects INGOTEPA 85108 and RugDisMar 155793), SEPCONACYT (CB-2011-01-168173), and ANUIES-ECOS (M09-U01). RD acknowledges support from UABC and CONACYT for a sabbatical leave. VGT received a doctoral scholarship from CONACYT and a POGO visiting fellowship. Special thanks to Mónica Sánchez, Julieta Castro, Carmen Labastida, and Ivonne Best for logistical and administrative help, and to the reviewers and editors whose valuable comments helped to improve this paper.

English translation by Christine Harris.

\section{REFERENCES}

Ardhuin F, Herbers THC, van Vledder GP, Watts KP, Jensen R, Graber HC. 2007. Swell and slanting-fetch effects on wind wave growth. J. Phys. Oceanogr. 37: 908-931.

Barrick DE. 1972. First-order theory and analysis of MF/HF/VHF scatter from the sea. IEEE Transactions on Antennas and Propagation 20: 2-9.

Barrick DE. 1977. The ocean wave height non-directional spectrum from inversion of HF sea-echo Doppler spectrum. Remote Sens. Environ. 6: 201-227.

Barrick DE, Headrick JM, Bogle RW, Crombie DD. 1974. Sea backscatter at HF: Interpretation and utilization of the echo. Proc. IEEE 62: 673-680.

Bottema M, van Vledder GP. 2008. Effective fetch and non-linear four-wave interactions during wave growth in slanting fetch conditions. Coast. Eng. 55: 261-275.

Bottema M, van Vledder GP. 2009. A ten-year data set for fetch- and depth-limited wave growth. Coast. Eng. 56: 703-725.

Breivik O, Saetra O. 2001. Real time assimilation of HF radar currents into a coastal ocean model. J. Mar. Syst. 28: 161-182.

Crombie DD. 1955. Doppler spectrum of sea echo at $13.56 \mathrm{Mc} / \mathrm{s}$. Nature 175: 681-682.

Donelan MA. 1987. The effect of swell on the growth of windwaves. Johns Hopkins APL Tech. Dig. 8: 18-23.

Ebuchi N. 1999. Growth of wind waves with fetch in the Sea of Japan under winter monsoon investigated using data from satellite altimeters and scatterometer. J. Oceanogr. 55: 575-584. sin embargo, nótese que los valores de $H_{S W E L L}$ son independientes del oleaje local y del viento, mientras que wsf cuantifica de manera indirecta los valores de $H_{S W E L L}$. Los resultados obtenidos con estas dos variables mostraron claras diferencias entre sí. La distribución casi aleatoria de los valores de $H_{S W E L L}$ respecto a las curvas empíricas sugiere que son los valores de $E_{S E A}$ los que varían significativamente. La presencia de valores de $H_{S W E L L}$ de $\sim 0.6 \mathrm{~m}$ por debajo de las curvas empíricas podría estar relacionada con los errores en el cálculo del espectro en frecuencia. Por otro lado, el factor wsf representa la variación de $E_{S E A}$ respecto a $E_{T O T} \mathrm{y}$, en este trabajo, los valores de wsf mostraron una clara relación con $\boldsymbol{X}$. Debido a que los valores de $X$ varían en menor proporción que $U_{10}{ }^{2}$ y ya que $\boldsymbol{X}$ es inversamente proporcional a $U_{10}{ }^{2}$, los valores de de wsf entre 0.5 y 0.85 asociados a $\boldsymbol{X}<10^{3}$ muestran una clara influencia de valores altos de viento. De la misma manera, valores de $w s f \leq 0.5$ asociados a $X \geq 10^{3}$ están relacionados con valores bajos de viento. El comportamiento de los valores de $H_{S W E L L}$ y wsf utilizados en este trabajo respecto a las curvas empíricas no presentó una evidencia clara que permita definir la influencia del swell en el crecimiento del oleaje.

La posible influencia del swell en el crecimiento del oleaje también se puede analizar a partir del comportamiento de los ajustes lineales y los valores medios calculados. En el primer caso, se observó una correlación significativa de los ajustes lineales de los valores de $\boldsymbol{E}_{S E A}$ y $\boldsymbol{F}_{S E A}$ con los datos de radar HF y las curvas empíricas de Kahma y Calkoen (1992) y Hwang et al. (2011); por lo tanto, los ajustes lineales no permiten sugerir alguna influencia del swell en el crecimiento del oleaje. Los valores medios de $\boldsymbol{E}_{\text {SEA }}$ y $\boldsymbol{F}_{\text {SEA }}$ calculados con información de los 25 nodos cercanos a la boya ASIS también se encontraron cercanos a las curvas empíricas. Solamente en el caso de $\boldsymbol{E}_{\boldsymbol{S E A}}$, cuando $\boldsymbol{X}>2.5 \times 10^{3}$, se observaron valores por debajo de las curvas empíricas, lo cual podría representar una ligera evidencia de la influencia del swell en el crecimiento del oleaje.

Numerosos autores han estudiado la influencia del swell en el crecimiento del oleaje. Los experimentos de laboratorio (Mitsuyasu 1966, Donelan 1987) han mostrado que la presencia de ondas largas reduce drásticamente el crecimiento del oleaje. Kahma y Calkoen (1992) supusieron que $E_{S W E L L}$ fue la causa de la dispersión de datos en el análisis del crecimiento del oleaje; sin embargo, aunque sus resultados no mostraron cambios significativos en $E_{S E A}$ debido a $H_{S W E L L}$, sugieren que el swell con pendientes pronunciadas podría influir en el crecimiento del oleaje. Por el contrario, Ardhuin et al. (2007), mediante análisis de datos in situ y modelación numérica, encontraron que los valores moderados de $E_{S W E L L}$ opuestos al oleaje local no tienen un impacto significativo en el crecimiento del oleaje limitado por el fetch. García-Nava et al. (2012) sugieren que el swell atenúa las olas cortas pero consideran que su efecto sobre el crecimiento del oleaje es en general despreciable. Los análisis realizados en este trabajo 
Flores-Vidal X, Durazo R, Chavanne C, Flament P. 2011. Coastal circulation in the absence of wind in the Gulf of Tehuantepec, Mexico: High-frequency radar observations. Cienc. Mar. 37: 493-512.

García-Nava H, Ocampo-Torres FJ, Osuna P, Donelan MA. 2009. Wind stress in the presence of swell under moderate to strong wind conditions. J. Geophys. Res. 114: 1-12.

García-Nava H, Ocampo-Torres FJ, Hwang PA, Osuna P. 2012. Reduction of wind stress due to swell at high wind conditions. J. Geophys. Res. 117: C00J11. http://dx.doi.org/10.1029/2011JC007833.

Gurgel K-W, Essen H-H, Schlick T. 2006. An empirical method to derive ocean waves from second-order Bragg scattering: Prospects and limitations. IEEE J. Ocean. Eng. 31: 804-811.

Hanson JL, Phillips OM. 2001. Automated analysis of ocean surface directional wave spectra. J. Atmos. Ocean. Technol. 18: 277-293.

Hashimoto N, Tokuda MA. 1999. A Bayesian approach for estimating directional spectra with HF radar. Coast. Eng. 41: 137-149.

Hasselmann K. 1971. Determination of ocean wave spectra from Doppler radio return from the sea surface. Nature 229: 16-17.

Hasselmann K, Barnett TP, Bouws E, Carlson H, Cartwright DE, Enke K, Ewing JA, Gienapp H, Hasselmann DE, Kruseman P, Meerburg A, Müller P, Olbers DJ, Richter K, Sell W, Walden H. 1973. Measurements of wind-wave growth and swell decay during the Joint North Sea Wave Project (JONSWAP). Deutsche Hydrogr. Z. Suppl. A(8) 12: 95 pp.

Heron ML, Heron SF. 2001. Cumulative probability noise analysis in geophysical spectral records. Int. J. Remote Sens. 22: 2537-2544.

Hisaki Y. 1996. Nonlinear inversion of the integral equation to estimate ocean wave spectra from HF radar. Radio Sci. 31: 25-39.

Hwang PA, García-Nava H, Ocampo-Torres FJ. 2011. Observations of wind wave development in mixed seas and unsteady wind forcing. J. Phys. Oceanogr. 41: 2343-2362.

Hwang PA, Ocampo-Torres FJ, García-Nava H. 2012. Wind sea and swell separation of 1D wave spectrum by a spectrum integration method. J. Atmos. Ocean. Technol. 29: 116-128.

Kahma KK. 1981. A study of the growth of the wave spectrum with fetch. J. Phys. Oceanogr. 11: 1503-1515.

Kahma KK, Calkoen CJ. 1992. Reconciling discrepancies in the observed growth of wind-generated waves. J. Phys. Oceanogr. 22: 1389-1405.

Kitaigorodskii SA. 1962. Applications of the theory of similarity to the analysis of wind-generated wave motion as a stochastic process. Izv. Akad. Nauk SSSR Geophys. Ser. 1: 105-117.

Lipa BJ, Barrick DE, Maresca Jr JW. 1981. HF radar measurements of long ocean waves. J. Geophys. Res. 86(C5): 4089-4102.

Mitsuyasu H. 1966. Interactions between water waves and wind. Rep. Inst. Appl. Mech. 14: 67-88.

Ocampo-Torres FJ, García-Nava H, Durazo R, Osuna P, DíazMéndez GM, Graber HC. 2011. The INTOA Experiment: A study of ocean-atmosphere interactions under moderate to strong offshore winds and opposing swell conditions in the Gulf of Tehuantepec, Mexico. Bound-Lay Meteorol. 138: 433-451.

Pantoja DA, Marinone SG, Parés-Sierra A, Gómez-Valdivia F. 2012. Numerical modeling of seasonal and mesoscale hydrography and circulation in the Mexican Central Pacific. Cienc. Mar. 38: 363-379.

Romero L, Melville WK. 2010. Airborne observations of fetchlimited waves in the Gulf of Tehuantepec. J. Phys. Oceanogr. 40: 441-465.

http://dx.doi.org/10.1175/2009JPO4127.1 no presentaron evidencias claras de una posible influencia del swell en el crecimiento del oleaje.

En el presente trabajo se obtuvieron valores de $\boldsymbol{E}_{\text {SEA }} \mathrm{y}$ $\boldsymbol{F}_{\boldsymbol{S E A}}$ en función de $\boldsymbol{X}$ asociados al crecimiento del oleaje cercanos a las curvas empíricas de Kahma y Calkoen (1992) y Hwang et al. (2011). Los valores de crecimiento presentaron una dispersión poco significativa alrededor de las curvas mencionadas. Este trabajo es uno de los primeros esfuerzos enfocados al análisis de crecimiento del oleaje utilizando mediciones de radar HF. El espectro del oleaje calculado por medio de información de radar HF presentó una correlación significativa con los valores obtenidos de mediciones in situ. Estos resultados sugieren que se puede obtener información adecuada del oleaje mediante el método novedoso utilizado para procesar las mediciones de alta resolución espaciotemporal obtenidas con radares $\mathrm{HF}$ y el uso de un modelo paramétrico lineal en función de la velocidad del viento.

\section{Agradecimientos}

Este trabajo fue financiado por el Consejo Nacional de Ciencia y Tecnología (CONACYT, proyectos INGOTEPA 85108 y RugDisMar 155793), SEP-CONACYT (CB-201101-168173) y ANUIES-ECOS (M09-U01). RD agradece el apoyo económico de la UABC y CONACYT a través de una beca para una estancia sabática. VGT recibió apoyo de CONACYT y POGO para una beca de doctorado y una beca para una estancia de investigación, respectivamente. Agradecimientos especiales a Mónica Sánchez, Julieta Castro, Carmen Labastida e Ivonne Best por su apoyo logístico y administrativo. Una mención especial a los revisores y editores quienes, con sus comentarios, permitieron un mejoramiento sustancial en la calidad de este trabajo.

Toro VG. 2014. Estudio sobre el crecimiento del oleaje limitado por el fetch en presencia de swellÂ utilizando radares de alta frecuencia. PhD Thesis, Centro de Investigación Científica y de Educación Superior de Ensenada, Ensenada, Baja California, Mexico. 145

pp.

Tracy B, Devaliere E-M, Hanson J, Nicolini T, Tolman H. 2007. Wind sea and swell delineation for numerical wave modeling. 10th International Workshop on Wave Hindcasting and Forecasting and Coastal Hazard Symposium. Oahu, Hawaii, pp. 11-16.

Tuomi L, Kahma KK, Fortelius C. 2012. Modelling fetch-limited wave growth from an irregular shoreline. J. Mar. Syst. 105-108: 96-105.

Velázquez-Muñoz FA, Martínez JA, Chavanne C, Durazo R, Flament P. 2011. Wind-driven coastal circulation in the Gulf of Tehuantepec, Mexico. Cienc. Mar. 37: 443-456.

Velázquez-Muñoz FA, Martínez JA, Durazo R. 2014. Numerical simulation of ocean response by offshore wind stress events. In: Klapp et al. (eds.), Experimental and Computational Fluid Mechanics. Springer-Verlag, pp. 93-110.

Walsh EJ, Hancock DW, Hines DE, Swift RN, Scott JF. 1989. An observation of the directional wave spectrum evolution from shoreline to fully developed. J. Phys. Oceanogr. 19: 670-690. 
Wyatt LR. 1989. Measuring the ocean wave directional spectrum with HF radar: The inversion problem. In: Brooks S (ed.), Mathematics in Remote Sensing. Clarendon Press, Oxford, pp. 279-291.

Wyatt LR. 1990. A relaxation method for integral inversion applied to HF radar measurement of the ocean wave directional spectra. Int. J. Remote Sens. 11: 1481-1494.

Wyatt LR. 2012. Use of HF radar for marine renewable applications. Proc. Oceans 2012, Yeosu, Korea, 5 pp.
Wyatt LR, Green JJ, Gurgel K-W, Nieto Borge JC, Reichert K, Hessner K, Günther H, Rosenthal W, Saetra O, Reistad M. 2003. Validation and intercomparisons of wave measurements and models during the EuroROSE experiments. Coast. Eng. 48: $1-28$.

Young IR, Verhagen LA. 1996. The growth of fetch limited waves in water of finite depth. Part 1 . Total energy and peak frequency. Coast. Eng. 29: 47-78.

http://dx.doi.org/10.1016/S0378-3839(96)00006-3

Received February 2014, accepted May 2014. 